\title{
Karışık baltalık ormanların sahil çamına dönüştürülmesinin toprak ve ölü örtüdeki organik karbon ve besin maddesi stoklarına etkisi
}

The effect of mixed coppice forests conversion to maritime pine plantations on soil and litter organic carbon and nutrient stocks

Selin ÖZBAY ${ }^{1}$ (D)

Doğanay TOLUNAY2

\footnotetext{
${ }^{1}$ Kavak ve Hızlı Gelişen Orman Ağaçları Araştırma Enstitüsü Müdürlüğü, İzmit

2 İstanbul Üniversitesi-Cerrahpaşa, Orman Fakültesi, İstanbul
}

Sorumlu yazar (Corresponding author) Doğanay TOLUNAY

dtolunay@istanbul.edu.tr

Geliş tarihi (Received)

04.05 .2020

Kabul tarihi (Accepted)

20.08.2020

Sorumlu editör (Corresponding editor) Şükrü Teoman GÜNER stguner@gmail.com

Atıf (To cite this article): Özbay, S, Tolunay, D (2021). Karıșık baltalık ormanların sahil çamına dönüştürülmesinin toprak ve ölü örtüdeki organik karbon ve besin maddesi stoklarına etkisi. Ormancılık Araștırma Dergisi, 8 (1), 12-26. DOI: https://doi.org/10.17568/ogmoad.731934

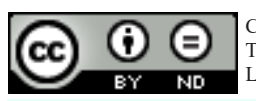

Creative Commons Atıf Türetilemez 4.0 Uluslararas isansı ile lisanslanmıştır.

\section{Öz}

Çalışmada karıșık baltalık ormanın ibreli saf ormana dönüştürülmesinin, bu ibreli ormanın yeniden aynı türle ve baltalık ormanın tıraşlanarak baltalık şeklinde gençleştirilmesinin ölü örtü ve toprak özellikleri üzerine etkisinin belirlenmesi amaçlanmıștır. Bu amaçla hızlı gelişen türlerle ağaçlandırmaların gerçekleştirildiği Kerpe Araştırma Ormanında (Kocaeli, Türkiye) çalışılmıştır. Çalışmada toplam 34 alan örneklenmiştir (yaşlı baltalıklar (YY), baltalıkların tıraşlanmasından sonra dikilen kırklı yaşlı 1. nesil sahil çamı (Pinus pinaster Aiton) ağaçlandırmaları (1NÇm) ve yaşlı sahil çamı ağaçlandırmalarının tıraşlanıp yeniden sahil çamı dikilen on yaşındaki ikinci nesil sahil çamı alanlarından (2NÇm) onar örnek alan; yaşlı baltalıkların tıraşlanması ile gelişen on yaşındaki genç yapraklı baltalıklardan (GY) 4 örnek alan). Çalışma sonucunda 2NÇm alanı ölü örtüdeki karbon ve besin maddesi stoklarının önemli derecede azaldığ 1 ve 10 yıllık dönemde $1 \mathrm{NCCm}$ alanlarıyla oluşan farkların kapanmadığ 1 belirlenmiştir. Topraklardaki organik karbon stokları $2 \mathrm{NÇm}$ alanda $1 \mathrm{NCCm}$ alana göre \%31, GY alanda YY alana göre \%28 oranında daha yüksek bulunmasına rağmen bu farkların istatistiksel açıdan önemli olmadığı belirlenmiştir. Benzer durum azot stokları için de söz konusudur. Fosfor stokları ise $2 \mathrm{NCm}$ ve GY alanlarda YY alanlara göre sırasıyla $\% 73$ ve $\% 71$ kadar azdır ve bu farklılık istatistiksel açıdan önemlidir. K ve Mg stokları arasında önemli farklar tespit edilmemiş, ancak azalmaların olduğu dikkat çekmiştir. Sonuç olarak tür değişikliğinin ve 2. nesil ağaçlandırmaların ölü örtü ve topraklardaki karbon ve besin maddesi stoklarını etkilediği ortaya konmuştur.

Anahtar Kelimeler: Hızlı gelişen türler, ağaçlandırma, rotasyon, $P i$ nus pinaster

\begin{abstract}
In this study, the aim was to determine the effects of various practices on litter and soil properties by regenerating a mixed coppice forest into a coniferous forest, regenerating the same coniferous forest with the same species and clear-cutting a coppice forest for regenerating via coppicing. For this purpose, the study was conducted at Kerpe Research Forest (Kocaeli, Turkey), where reforestation with fast-growing species had been carried out. In the study, a total of 34 sample areas were worked on (10 plots each from old coppice stands (YY), 40-year-old $1^{\text {st }}$ generation maritime pine (Pinus pinaster Aiton) reforestation $(1 \mathrm{NCCm})$ planted after clear-cutting of the old coppices and 10 -year-old maritime pine plantations $(2 \mathrm{NÇm})$, where $1^{\text {st }}$ generation of the aforementioned maritime pine reforestation was clear-cut; 4 plots from a 10-year-old young coppice stands (GY) growing after clear-cutting of the old coppices). It was determined that the amount of carbon and nutrient stocks in the litter were decreased significantly in $2 \mathrm{NCCm}$ and the differences within the $1 \mathrm{NÇm}$ plots did not close in the 10 -year period. Although the organic carbon stocks in soil samples of $2 \mathrm{NCCm}$ were $31 \%$ higher than $1 \mathrm{NCCm}$ and the organic carbon stocks of GY were $28 \%$ higher than YY, these differences were not found to be statistically significant. The results of nitrogen stocks were similar as well. The phosphorus stocks of $2 \mathrm{NÇm}$ and GY were $73 \%$ and $71 \%$ lower than YY, respectively. They were determined to be statistically significant. No significant differences were detected between the K and $\mathrm{Mg}$ stocks, but the decreases were noted. As a result, it has been demonstrated that species change and $2^{\text {nd }}$ generation reforestation practices affect carbon and nutrient stocks in litter and soils.
\end{abstract}

Keywords: Fast growing species, reforestation, rotation, Pinus pinaster 


\section{Giriş}

Türkiye'de sahil çamı (Pinus pinaster Aiton) ilk defa 1885-1887 yılları arasında, Durusu (Terkos) Gölü’nün (İstanbul, Çatalca) kuzeyindeki kumulu durdurmak için kullanılmıştır. 50 yıl kadar önce de başta Batı Karadeniz ve Marmara Bölgeleri olmak üzere daha geniş alanlarda ağaçlandırmalar başlamış ve bu ağaçlandırmalar Orman Genel Müdürlügünün (OGM) 2015 yılı verilerine göre 57.567 ha'a ulaşmıştır (OGM, 2016). Sahil çamı, hızlı büyümesi, kanaatkâr olması ve odununun kıymetli olması vb. özellikleriyle endüstriyel ağaçlandırmalarda tercih edilen türlerin başında gelmektedir (Saatçioğlu, 1969; Tunçtaner ve ark., 1985). Nitekim 2013 yılında yürürlüğe giren Endüstriyel Ağaçlandırma Çalışmaları Eylem Planında yine Batı Karadeniz ve Marmara Bölgelerinde sahil çamı ile ağaçlandırmalar yapılması yer almıştır (OGM, 2013). Bu bölgelerdeki endüstriyel ağaçlandırmalarda sahil çamına öncelik verilmesinin nedeni bu türün ince tekstürlü, kireçsiz ve hafif asit toprakları tercih etmesi (Özel ve ark., 2020) ve 50’li yaşlarına ulaşan mevcut sahil çamı ağaçlandırmalarının yine 2. nesil olarak sahil çamı ile gençleştirilmek istenmesidir.

Hızlı gelişen türlerle yapılan ağaçlandırmalar aslında tam alanda tıraşlama ile mevcut ağaçların hasat edilmesi, hasat sonrasında çoğunlukla köklerin sökülmesi ve diri örtü temizliği yapılması, toprak işleme şeklindeki arazi hazırlıklarını içeren çalışmalardır. Yapılan bu üretim ve arazi hazırlığ çalışmalarının niteliği ve yoğunluğuna bağlı olarak ölü örtü ve toprak üzerindeki etkileri de farkl1lık gösterebilmektedir. Dünyada sonuçlandırılan araştırmaların bazılarında; endüstriyel ağaçlandırmalarda saha hazırlığı esnasında organik madde kaynaklarından olan kök, dal ve ölü örtünün sahadan uzaklaştırılmasının karbon ve besin maddesi stoklarının azalmasına yol açtığ 1 (Zhang ve ark., 2004; Chen ve ark., 2005; Jandl ve ark., 2007; Clarke ve ark., 2015; Li ve ark., 2015), 2. ve 3. rotasyon ağaçlandırmalarda da benzer durumun söz konusu olduğu ifade edilmektedir (Zhang ve ark., 2004). Topraklardaki besin maddesi stoklarının azalmasının ise 2. ve 3. rotasyonlardaki ağaçların gelişmesini yavaşlatabileceği ifade edilmektedir (Walmsley ve ark., 2009; Clarke ve ark., 2015). Buna karş1lık örneğin kesim artıklarının sahada bırakılması (Wall, 2008; Wall ve Hytönen, 2011) ya da sahaya yoğun diri örtü gelmesi halinde (Makineci, 1999) ağaçlandırmadan sonraki ilk yıllarda ölü örtü miktarının arttığ 1 yönünde bulgular da bulunmaktadır. Benzer şekilde tür değișikliği ya da tıraşlama kesimlerle toprak organik karbon stoklarında (TOK) (Ferré ve ark., 2014) ve topraktaki bitki besin maddesi kapsamlarında azalmalar olduğu (Arocena,
2000; Thiffault ve ark., 2011), ancak kapalılığın oluşması ile yaprak dökümüne bağlı olarak arttı$\breve{g}_{1}$ ifade edilmektedir (Peihua ve ark., 2000). Buna karşılık 2. rotasyon ağaçlandırmalarda toprakların organik madde içeriklerinin değişmediği yönünde bulgulara ulaşılmıştır (Peihua ve ark., 2000). Egnell ve ark. (2015) hasat sonrasında köklerin sökülmesi ve derin toprak işleme şeklindeki arazi hazırlıklarının TOK stoklarını azalttığını buna karşılık ağaçların bitkisel kütlelerindeki karbon stoklarının artmasına bağlı olarak ormandaki toplam karbon (ağaçlar+toprak) stoklarının önemli derece değişmediğini belirlemişlerdir. Nave ve ark. (2010) toprak organik karbon (TOK) stoklarının USDA (ABD Tarım Bakanlığı) toprak taksonomisine göre Alfisoller ve Spodosollerde hasat sonrasında değişmediğini, buna karşılık ise Inceptisoller ve Ultisollerde ise hasat sonrasında TOK stoklarında önemli azalmalar olduğunu açıklamaktadırlar.

Birbiriyle örtüşmüyor gibi görünen bu araştırma sonuçlarının nedeni tür değişikliği ya da tıraşlama kesimler ve sonrasındaki arazi hazırlıkları ile sadece toprağa giren organik madde miktarının değil aynı zamanda birçok ekolojik sürecin de değiştirilmesidir. Örneğin tıraşlama ile birlikte toprağa ulaşan ve toprak içinde sızan su miktarı, evapotranspirasyon, intersepsiyon, yüzeysel akış, 1ş1k ve sıcaklık gibi faktör etkilenmektedir (Palviainen ve ark., 2014). Yine makineli toprak işleme toprağ 1 gevşeterek yıkanmayı arttırabildiği gibi, özellikle killi topraklarda sıkışmaya yol açarak drenaj sorunları da yaratabilmektedir (Clarke ve ark., 2015).

Türkiye'deki sahil çamı ağaçlandırmaları çoğunlukla yapraklı ormanların tıraşlanarak tür değişikliğine gidilmesi şeklinde uygulanmıştır. Tıraşlama sonrasında yoğun arazi hazırlığı çalışmaları yapılmış, bu kapsamda diri örtü temizliği ve riperleme gibi toprak işleme uygulamaları gerçekleştirilmiştir. Ülkemizde sahil çamı ağaçlandırmaları için yapılan tür değişikliğinin ve arazi hazırlığının ölü örtü ve toprak özellikleri üzerine etkisi konusunda bazı çalışmalar mevcuttur (Kantarcı, 1981; Kantarc1, 1982; Kantarc1, 1983; Tolay ve ark., 1983; Hizal ve ark., 1991; Hizal ve ark., 2015). Ancak 2. nesil olarak adlandırılan, başka bir ifadeyle tür değişimine gidilerek hızlı gelişen türler ağaçlandırılan bir alanın tıraşlanarak yeniden hızlı gelişen türle ağaçlandırılmasının ölü örtü ve toprak besin maddelerine etkileri konusunda yurt dişında araştırmalar bulunsa da ülkemizde bir çalışmaya rastlanmamıştır. Buradan hareketle yapılan bu çalışmayla yapraklı ormanın tıraşlanarak yerine sahil çamı dikilmesinin, yaşıı sahil çamı ağaçlandırmasının kesilerek yine aynı türle ağaçlandırılmasının (2. nesil) ve yapraklı ormanın tıraşlanmasının, toprak 
ve ölü örtüde meydana getirdiği etkilerin belirlenmesi amaçlanmıştır.

\section{Materyal ve Yöntem}

\subsection{Materyal}

\subsubsection{Mevkii ve yeryüzü şekli}

Kerpe Araştırma Ormanı, Kocaeli İli, Kandıra İlçesi, Kerpe yöresinde bulunmaktadır. $41^{\circ} 07^{\prime} 40^{\prime \prime}$ $41^{\circ} 09^{\prime} 00^{\prime \prime}$ kuzey enlemleri ile $30^{\circ} 09^{\prime} 30^{\prime \prime}-30^{\circ} 12^{\prime}$ $00^{\prime \prime}$ doğu boylamları arasında yer almaktadır. Arazi derelerle bölümlere ayrılmış olup, topoğrafyası dalgalıdır ve en yüksek yeri 154 m yüksekliğindeki bir tepedir (Gaddas, 1976) (Şekil 1).

\subsection{2. İklim}

İzmit Meteoroloji İstasyonunun 1993-2014 y1lları arasında yaptığı ölçümlere göre yıllık ortalama sicaklik 15,3 ${ }^{\circ} \mathrm{C}$ 'dir (MGM, 2015). En sicak aylar $22,3{ }^{\circ} \mathrm{C}, 24,7{ }^{\circ} \mathrm{C}$ ve $24,6{ }^{\circ} \mathrm{C}$ ortalama değerler ile sirasıyla haziran, temmuz ve ağustos ayları, en soğuk aylar ise $6,7^{\circ} \mathrm{C}$ ve $7,2^{\circ} \mathrm{C}$ ile sirasiyla ocak ve şubat aylarıdır. Temmuz ayında $44,1^{\circ} \mathrm{C}$ en yüksek, ocak ayında $-9,7^{\circ} \mathrm{C}$ en düşük sıcaklık olarak tespit edilmiştir. $30,7^{\circ} \mathrm{C}$ yıllık ortalama yüksek sıcaklık değeri olup, yıllık ortalama düşük sıcaklık değeri ise $11,4{ }^{\circ} \mathrm{C}$ 'dir. Y1llık ortalama yağ 1 ş $781,7 \mathrm{~mm}$ 'dir. Yağ 1 , , ortalama olarak aralık aylarında $108,3 \mathrm{~mm}$ ile en fazla değere ulaşmakta, mayıs aylarında 41,4 $\mathrm{mm}$ ile en az değere düşmektedir. Yıllık ortalama bağıl nem \%74,8'dir. Ocak ve şubat aylarında en fazla üç gün karla örtülüdür (Tablo 1). Thornthwaite yöntemine göre iklim tipi; "Yarı nemli, mezotermal, yazın orta derecede su eksikliği olan, okyanus iklimine yakın iklim" olarak belirlenmiştir (Thornthwaite, 1948).

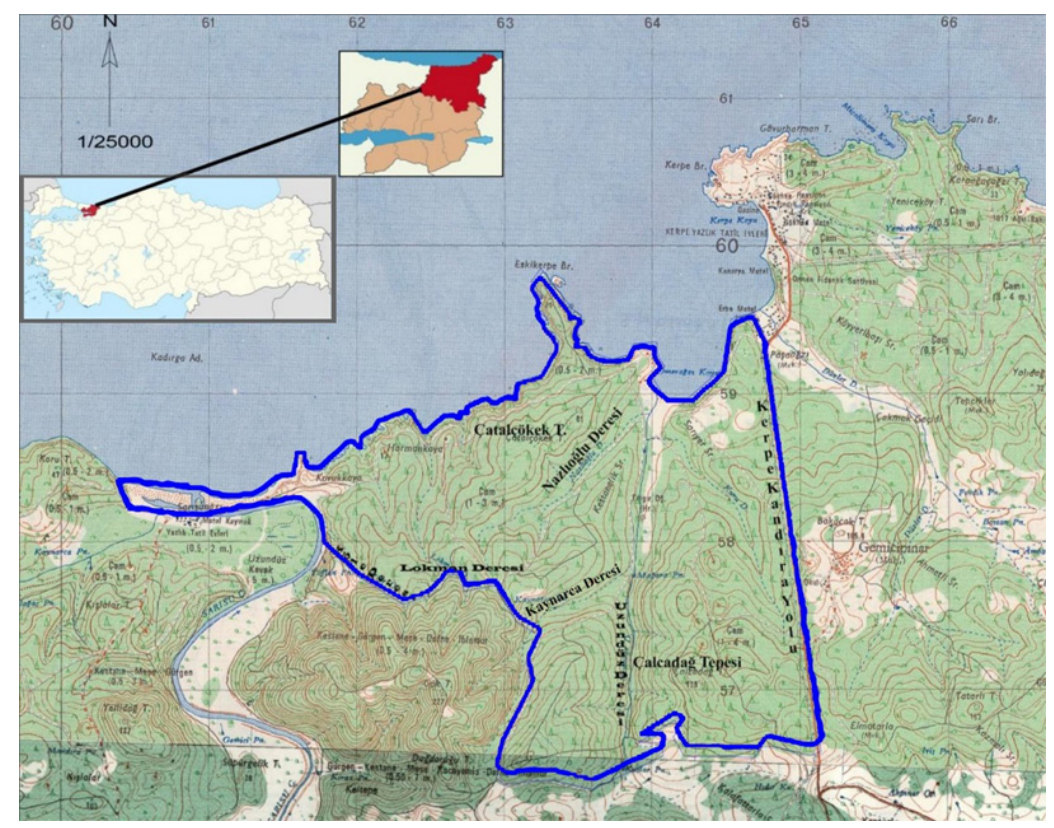

Şekil 1. Kerpe Araştırma Ormanı

Figure 1. Kerpe Research Forest

\subsubsection{Anakaya ve toprak}

Çalışmanın yapıldığı Kerpe Araştırma Ormanında sedimenter ve volkanik jeolojik formasyonlar görülmektedir (Özyuvacı, 1978). Uzundere civarında kil ağırlıklı, Göktepe yamaçlarında ise kum ağırlıklı birikintiler yer almaktadır (Gaddas, 1976). Topraklar killi, taşsız ve derin esmer orman toprağı (Eutric cambisol) sınıfındadır (Hızal ve ark., 2010). Örnek alınan yerlerin (Şekil 1) toprak tipi ise boz esmer orman toprağ ${ }_{1}$ (Luvisol) sınıfında ve kil içeriği \% $\%$ 25,5 ile \%76 arasında değişmekte olup, orta şiddette asittir. Besin maddesince yeterli olan toprağın üst kısımları organik madde bakımından zengindir (Gaddas, 1976). Çalışma alanındaki ölü örtü tipi çürüntülü muldur.

\subsubsection{Bitki örtüsü}

Kerpe Araştırma Ormanı; Kavak ve Hızlı Gelişen Orman Ağaçları Araştırma Enstitüsünce 1972 ve 1977 yılları arasında "TUR 71/521 Projesi” olarak hızlı gelişen türlerle tesis edilmiştir (Hızal ve ark, 2015). Projede sahil çamı, radiata çamı (Pinus radiata D. Don), kızılçam (Pinus brutia Ten.), Halep çamı (Pinus halepensis Mill.), karaçam (Pinus nigra Arnold), douglas göknarı (Pseudotsuga menziesii (Mirb.) Franco), Taeda çamı (Pinus taeda L.) 
ve okaliptus (Eucalyptus sp.) türleri kullanılmıştır. Araştırma ormanında doğal ağaç türleri olarak Anadolu kestanesi (Castanea sativa Mill.), saçlı meşe (Quercus cerris L.), Macar meşesi (Quercus frainetto Ten), sapsı meşe (Quercus petraea (Matt.) Liebl.), doğu kayını (Fagus orientalis Lipsky), adi gürgen (Carpinus betulus L.), titrek kavak (Populus tremula L.) ve ihlamur (Tilia argantea Desf.Ex DC) yayılış göstermektedir. Ayrıca ağaççık ve çalı katında rastlanan türler ise Akde- niz defnesi (Laurus nobilis L.), kocayemiş (Arbutus unedo L.), muşmula (Mesphilus germanica L.), akçakesme (Phillyrea latifolia L.), mor çiçekli ormangülü (Rhododendron ponticum L.), sırım başı (Daphnea pontica L.), domuz ayrığ1 (Dactylis glomerata L.), orman sarmaşı̆̆ 1 (Hedera helix L.), böğürtlen ve ahududu (Rubus sp.), laden (Cistus sp.) ve kartal eğreltisi (Pteridium aquilinum (L.) Kuhn.)'dir (Gaddas ve Öz, 1975; Ercan, 2002).

Tablo 1. İzmit Meteoroloji İstasyonunun 1993-2014 dönemine ait meteorolojik verileri (MGM, 2015)

Table 1. Meteorological data of Izmit Meteorology Station for the period 1993-2014 (MGM, 2015)

\begin{tabular}{|c|c|c|c|c|c|c|c|c|c|c|c|c|c|}
\hline \multirow{2}{*}{ Meteorolojik Elemanlar } & \multicolumn{12}{|c|}{ Aylar } & \multirow{2}{*}{ Y1ll1k } \\
\hline & $\mathrm{I}$ & II & III & IV & $\mathrm{V}$ & VI & VII & VIII & IX & $\mathrm{X}$ & XI & XII & \\
\hline Aylık Ort. Yağış (mm) & 97,6 & 76,1 & 84,4 & 55,6 & 41,4 & 50,4 & 42,2 & 53,6 & 51,7 & 92,7 & 83,0 & 108,3 & 837,0 \\
\hline Aylık Ort. Sicaklık $\left({ }^{\circ} \mathrm{C}\right)$ & 6,7 & 7,2 & 9,0 & 13,3 & 18,2 & 22,3 & 24,7 & 24,6 & 20,9 & 16,3 & 12,0 & 8,6 & 15,3 \\
\hline $\begin{array}{l}\text { Aylık Ort. En Yüksek S1- } \\
\text { caklık }\left({ }^{\circ} \mathrm{C}\right)\end{array}$ & 10,2 & 11,3 & 13,9 & 18,7 & 24,1 & 28,1 & 30,7 & 30,5 & 26,6 & 21,1 & 15,4 & 12,1 & 30,7 \\
\hline $\begin{array}{l}\text { Aylık Ort. En Düşük S1- } \\
\text { caklık }\left({ }^{\circ} \mathrm{C}\right)\end{array}$ & 3,7 & 3,8 & 5,2 & 9,0 & 13,4 & 17,4 & 20,0 & 20,1 & 16,6 & 12,9 & 8,5 & 5,6 & 11,4 \\
\hline En Yüksek Sicaklık $\left({ }^{\circ} \mathrm{C}\right)$ & 23,7 & 26,0 & 30,8 & 34,7 & 36,6 & 38,7 & 44,1 & 38,9 & 37,2 & 36,2 & 28,4 & 27,4 & 44,1 \\
\hline En Düşük Sicaklık $\left({ }^{\circ} \mathrm{C}\right)$ & $-9,7$ & $-6,7$ & $-3,8$ & $-0,9$ & 2,8 & 9,8 & 19,9 & 13,9 & 8,0 & 2,4 & $-0,7$ & $-3,9$ & $-0,9$ \\
\hline Aylık Ort. Bağıl Nem (\%) & 78,4 & 75,8 & 73,8 & 71,7 & 70,8 & 69,3 & 70,9 & 74,5 & 76,4 & 80,9 & 78,9 & 76,5 & 74,8 \\
\hline Karla Örtülü Gün Sayısı & 3,2 & 3,2 & 0,9 & - & - & - & - & - & - & - & - & 1,1 & 8,4 \\
\hline $\begin{array}{l}\text { Aylık Hâkim Rüzgâr } \\
\text { Şiddeti (m/sec) }\end{array}$ & 23,5 & 29,8 & 25,8 & 27,1 & 22,1 & 20,5 & 18,2 & 21,1 & 23 & 20,4 & 26 & 28,2 & 29,8 \\
\hline $\begin{array}{l}\text { Aylik Hâkim Rüzgâr } \\
\text { Yönü }\end{array}$ & $\mathrm{KB}^{*}$ & KB & KB & B & KB & K & KB & $\mathrm{K}, \mathrm{KB}$ & B & KB & $\mathrm{G}, \mathrm{GD}$ & KB & KB \\
\hline
\end{tabular}

\subsubsection{Araştırma alanının geçmişi}

Araştırma alanı, Sakarya Orman Bölge Müdürlügüü İzmit Orman İşletme Müdürlüğüne bağlı değişik işletme şeflikleri tarafından 1972 yılına kadar Orman Amenajman Planına göre yönetilmiştir. 1972 yılından sonra adı geçen TUR 71/521 projesi kapsamında, hızlı gelişen ibreli türlerle sahada ağaçlandırma çalışmalarına başlanmıştır (Cooling, 1977, Hızal ve ark., 2015). 1973 yılında diri örtü tıraşlanarak; tam alanda 40-60 cm derinlikte 4'lü riperle veya $30-50 \mathrm{~cm}$ derinlikte 3'lü riperle toprak işlemesi yapılmış, hafif/ağır diskaroyla üst toprak işlenmiş ve 1976 yılına kadar da dikimler tamamlanmıştır. 174,1 ha'lık doğal vejetasyon, karşılaştırma yapmak ve rüzgâr perdesi olarak kullanmak maksadıyla şeritler halinde bırakılmıştır (Ercan, 2002). İkinci nesil sahil çamlarının bulunduğu alan; anılan Enstitüsü Müdürlüğünün "İzmit, Kerpe Yöresinde Sahilçamı (Pinus pinaster Aiton) İkinci Kuşak Ağaçlandırmalarında Kullanılan Çeşitli Toprak İşleme Yöntemleri, Toprak Özellikleri ve Ağaç Büyümeleri Arasındaki İlişkiler” adlı projesi dâhilinde 2003 yılında tıraşlanarak, alanda beş farklı toprak işleme yöntemi (1: Tarak ile diriörtü temizliği + Tam alanda riper ile toprak iş- leme, 2: Tarak ile diri örtü temizliği + Pulluk ile şeritler halinde toprak işleme $(1,5 \mathrm{~m}), 3$ : Tarak ile diri örtü temizliği + Diskaro ile tam alan toprak işleme, 4: Tarak ile diri örtü temizliği+Tam alanda riper+Diskaro ile toprak işleme, 5 (Kontrol) Tarak ile diri örtü temizliği) uygulanmıştır.

\subsection{Yöntem}

\subsection{1. Örnek alanların seçimi}

Toprak ve ölü örtü örnekleri; aynı yetişme ortamındaki; kayın, gürgen, kestane türlerinin hakim olduğu baltalık kökenli yaşlı yapraklı ormandan (YY), yine baltalık kökenli on yaşındaki genç yapraklı ormandan (GY), kırklı yaşlardaki birinci nesil sahil çamı ağaçlandırmasından (1NÇm) ve bu ağaçlandırmaların tıraşlanıp yeniden sahil çamı dikilen on yaşındaki ikinci nesil sahil çamı ağaçlandırmasından (2NÇm) alınmıştır. Genç yapraklı ormanlardan 4, YY, $1 \mathrm{NÇm}$ ve $2 \mathrm{NÇm}$ alanlarından ise 10 'ar adet olmak üzere toplam 34 adet toprak çukuru açılmıştır (Şekil 2). Örneklemelerin yapıldığ 1 bölme numaraları, meşcere tipleri; bakı, yaş, yükselti, boy, çap ve ağaç özellikleri Tablo 2'de verilmiştir. 


\subsubsection{Toprak ve ölü örtü örneklemesi}

Açılan toprak çukurlarından 0-5 cm, 5-15 cm, 15$30 \mathrm{~cm}, 30-50 \mathrm{~cm}, 50-70 \mathrm{~cm}$ ve $70-100 \mathrm{~cm}$ derinlik kademelerinden bir litrelik silindirlerle toprak örnekleri, her çukurun etrafından $0,25 \times 0,25 \mathrm{~m}$ ebatlarındaki çerçeveyle beşer adet ölü örtü örneği alınmıştır.

\subsubsection{Laboratuvarda uygulanan yöntemler}

Laboratuvara getirilen toprak örnekleri hava kurusu hale gelene kadar kurutulmuş, tartılmış ve havanda öğüülmüştür. 2 mm'lik elekten geçi- rilerek taş ve kökler ayıklanmıştır. Taş ve kökler yıkanmış, kurutulmuş ve tekrar tartılmıştır. Her çukur etrafından $0,25 \times 0,25 \mathrm{~m}$ ebatlarındaki çerçeveyle alınan beşer adet ölü örtü örneği hava kurusu hale gelinceye kadar kurutulduktan sonra içlerindeki 5 cm'den kalın odunsu materyaller (dal, kozalak vb.) ayrılmıștır (Çömez, 2010). Daha sonra ölü örtü örnekleri teker teker tartılarak $0,5 \mathrm{~mm}$ elekten geçirilmiş ve eleğin altına geçen kısım humus olarak ayrılmıştır. Eleğin üzerinde kalan kısım ise yaprak+çürüntü $(\mathrm{Y}+\mathrm{C})$ olarak tek bir tabaka olarak değerlendirilmiştir. Analizler için her örnek alandan 5 farklı noktadan alınan örnekler birbirine karıştırılarak karma örnek oluşturulmuştur.

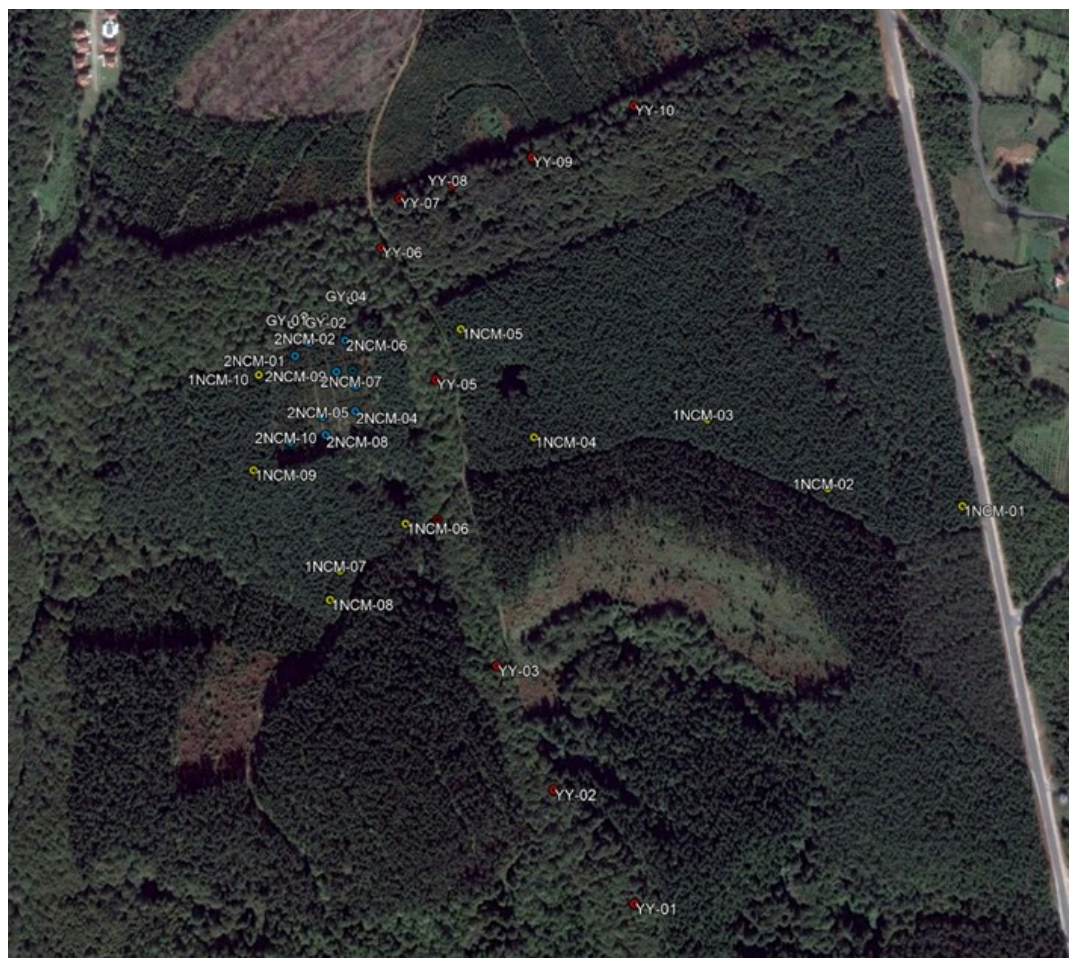

Şekil 2. Örnek alanların yerleri (YY: yaşlı yapraklı, GY: genç yapraklı, 1NÇm:birinci nesil sahil çamı, 2NÇm: ikinci nesil sahil çamı)

Figure 2. Locations of sample areas (YY: old broad-leaved, GY: young broad-leaved, 1NÇm: first rotation maritime pine, $2 \mathrm{NÇm:} \mathrm{second} \mathrm{rotation} \mathrm{maritime} \mathrm{pine)}$

Tablo 2. Örnek alanların bazı yetișme ortamı ve meșcere özellikleri

Table 2. Some habitats and stand characteristics of the sample areas

\begin{tabular}{|c|c|c|c|c|c|c|c|c|c|}
\hline $\begin{array}{l}\text { İşlem } \\
\text { Gruplar1 }\end{array}$ & $\begin{array}{l}\text { Bölme } \\
\text { No }\end{array}$ & $\begin{array}{l}\text { Meşcere } \\
\text { Tipi }\end{array}$ & $\begin{array}{l}\text { Eğim } \\
(\%)\end{array}$ & Bak1 & $\begin{array}{l}\text { Yükselti } \\
\text { (m) }\end{array}$ & Yaş & $\begin{array}{l}\text { Boy } \\
(\mathrm{m})\end{array}$ & Çap (cm) & Ağaç Türleri \\
\hline $1 \mathrm{NÇm}$ & $6,7,8$ & Çmcd3 & $5-20$ & K & 70 & 40 & $20-28$ & $36-40$ & sahil çamı \\
\hline $2 \mathrm{NÇm}$ & 8 & Çmb3 & $5-15$ & K & 75 & 10 & $6-10$ & $8-19,9$ & sahil çamı \\
\hline YY & $\begin{array}{l}6,7 \\
8,9\end{array}$ & KnGnKsbc3 & $5-20$ & $\begin{array}{l}\mathrm{K}, \mathrm{KB}, \\
\mathrm{GB}, \mathrm{GD}\end{array}$ & $50-75$ & $40-70$ & $8-16$ & $20-35,9$ & $\begin{array}{l}\text { kayin, gürgen, } \\
\text { kestane }\end{array}$ \\
\hline GY & 8 & KnGnKsab3 & $5-15$ & $\mathrm{~K}$ & 75 & 10 & $6-10$ & $6-19,9$ & $\begin{array}{c}\text { kayın, gürgen, } \\
\text { kestane }\end{array}$ \\
\hline
\end{tabular}

1NÇm:birinci nesil sahil çamı, 2NÇm: ikinci nesil sahil çamı, YY: yaşlı yapraklı, GY: genç yapraklı 
Toprakların tane çapları Bouyoucous hidrometre metoduyla tayin edilmiştir (Gülçur, 1974). pH ve elektriksel iletkenlik toprak örnekleri $1 / 5(\mathrm{~m} / \mathrm{v})$ oranında saf su ile 1slatıldıktan ve bir gece bekletildikten sonra belirlenmiştir (TS ISO 10390, 2013; TS ISO 11265, 1996). Kalsiyum karbonat, Scheibler kalsimetresi ile ölçülmüştür (Gülçur, 1974). Toplam azot ve organik karbon konsantrasyonu (\%) LECO Truspec 2000 CN Analyser cihaziyla analiz edilerek bulunmuştur. Çalışma alanımızdaki topraklar kireç içermediğinden bulunan karbon içeriği organik karbon olarak kabul edilmiştir. Değişebilir katyonlar ( $\mathrm{K}, \mathrm{Ca}, \mathrm{Mg})$, toprak örneklerinin $1 \mathrm{~N}$ amonyum asetat $\left(\mathrm{NH}_{4} \mathrm{OAc}\right)(\mathrm{pH}=7)$ ile yıkanması sonucunda çözeltiye geçen iyonların Atomik Absorpsiyon cihazında analiz edilmesiyle belirlenmiştir (Kacar, 2009). Toprakta fosfor asit topraklarda kullanılan Modifiye Bray ve Krutz No. 1 yöntemiyle tayin edilmiştir (TS 8338, 1990). Ölü örtü tabakalarındaki besin maddelerinin belirlenmesi için örnekler önce nitrik asit ve perklorik asit $\left(\mathrm{HNO}_{3}+\mathrm{HClO}_{4}\right)$ karışımında yakılmıştır. Sonra elde edilen çözeltilerden vanada molibdo fosforik sarı renk yöntemi ile fosfor belirlenmiş ve atomik absorpsiyon cihazıyla da potasyum, magnezyum ve kalsiyum ölçülmüştür (Kacar, 1972).

\subsection{4. İstatistik yöntemler}

Verilere varyans analizi uygulanmadan önce normalite testi uygulanarak, Kolmogorov-Smirnov’a göre değerlendirme yapılmıştır. Normal dağılım gösteren verilere varyans analizi (ANOVA) uygulanarak ağaçlandırmaların etkisi test edilmiş ve sonuçların önemli çıkması durumunda Duncan Çoklu Karşılaştırması yapılmıştır. Normal dağılmayan veriler; karekök, logaritmik veya ters dönüşüm yöntemlerinden biri kullanılarak dönüştürülmüştür. Dönüştürme işlemlerine rağmen normal dağılım göstermeyen veri setleri olması durumunda işlem grupları arasında fark olup olmadığ 1 , Non-Parametrik analizlerden biri olan Kruskal Wallis analizi ile denetlenmiştir. Kruskal Wallis testi ile farkların önemli bulunması halinde MannWhitney U testi ile işlem grupları ikili olarak karşılaştırılmıştır. Derinlik kademeleri ve işlem gruplarının etkileşimini belirlemek için İki Yönlü ANOVA Testi uygulanmıştır. Sonuçlar $\alpha=0,05$ olasılık düzeyinde istatistiki olarak farklı kabul edilmiştir. Analizlerde SPSS 22.0 paket programı kullanılmıştır (SPSS v.22.0®, 2015).

\section{Bulgular}

\subsection{Hacim ağırlığı, tekstür, $\mathrm{pH}$ ve EC}

$\mathrm{Bu}$ bölümde yer alan tüm değişkenlere ilişkin bulgular Tablo 3'te verilmiştir. Hacim ağırlıkla- r1, meşçere işlem grupları arasında sadece 15-30 cm derinlik kademesinde (Tablo 3) ve GY işlem grubunda daha yüksek bulunarak anlamlı bir farklılık göstermiştir. Topraklarda kum yüzdeleri, GY meşcerelerinin tüm derinlik kademelerinde yüksek bulunmuştur. Toz yüzdelerinin ise genç meşcerelerde yaşlı meşcerelere göre anlamlı düzeyde azaldığı tespit edilmiştir. Kil yüzdelerinin, GY'ye göre tüm grupların derinlik kademelerinin tamamında aynı grupta yer aldığı ve daha fazla olduğu bulunmuştur (Tablo 3).

GY meşceresinin 0-5 cm derinlik kademesinde en yüksek pH değeri bulunmasına rağmen 30 ve 70 $\mathrm{cm}$ derinlikleri arasında $1 \mathrm{NÇm}$ ile YY meşcerelerindeki anlamlı düzeyde artış dikkat çekmiştir. Elektriksel iletkenlik değerlerinin $15 \mathrm{~cm}$ derinlikten sonra, 1NÇm ile GY meşcerelerinde (70-100 $\mathrm{cm}$ haricinde) hem daha fazla olduğu hem de aynı grupta yer aldığı görülmüştür (Tablo 3).

\subsection{Toprak organik $C$ ve bazı besin maddeleri}

Organik karbon oranları; tüm örnek alanlarda 30 $\mathrm{cm}$ derinlikten sonra farklılık göstermemiştir. $\mathrm{Bu}$ oranlar 2NÇm ile GY alanlarında YY alanlarına göre yüksek olup 2NÇm'de ise bu oran daha yüksek bulunmuştur. Toplam azot oranları, tüm derinlik kademelerinde işlem grupları arasında istatistik analizlere göre farklılık göstermektedir. Özellikle 2NÇm ile GY alanlarında diğer gruplara göre fazla miktarda ölçülmüştür. Alınabilir fosfor konsantrasyonlarının, örnekleme alanları arasında anlamlı bir değişkenlik göstermese de YY ile $1 \mathrm{NÇm}$ alanlarında arttığ 1 ve her grubun $0-5 \mathrm{~cm}$ derinlik kademesinde benzer durumun olduğu fark edilmiştir (Tablo 4).

Değiştirilebilir $\mathrm{K}$ ve $\mathrm{C}$ konsantrasyonlarının ortalamaları istatiksel anlamda değişkenlik göstermemekle birlikte en fazla ve en az değer GY alanlarında yer almaktadır. Değiştirilebilir Mg değerleri istatistiki analizlerde sadece 70-100 derinlik kademesinde farklı çıkmıştır. 97,3 mg/kg magnezyum ile en fazla ortalama değer YY alanlarında bulunmuştur (Tablo 4).

\subsection{Toprak organik karbon ve bazı besin maddesi stokları}

TOK stoklar1 50-70 cm ve 70-100 cm derinlik kademelerinde farklılık göstermiştir. Karbon konsantrasyonlarında olduğu gibi genç meşcerelerde toplam TOK stoku yüksek bulunmuştur. 50-70 cm derinlik kademesi hariç $15 \mathrm{~cm}$ derinlikten $100 \mathrm{~cm}$ 'ye kadar azot miktarları anlamlı bir değişkenliktedir. GY ve 2NÇm alanlarında azot miktarları istatistiksel açıdan önemli olmasa da yüksektir (Tablo 5). 
Birinci nesil ibreli ve doğal yapraklı meşcere grupları ile diğer iki genç meşcere kıyaslandığında alınabilir fosforun toplamda daha fazla stoklandığ ve bunun anlamlı olduğu tespit edilmiştir.
Değiştirilebilir potasyum, kalsiyum ve magnezyum stok miktarları yapılan istatistiksel analizlerde benzer bulunmuştur (Tablo 5).

Tablo 3. Toprakların hacim ağırlı̆̆ı, tekstür, pH ve EC değerleri (Ortalama \pm Standart sapma) Table 3. Bulk density, texture, $\mathrm{pH}$ and EC values of soils (Mean \pm Standard deviation)

\begin{tabular}{|c|c|c|c|c|c|c|}
\hline \multirow{2}{*}{ İşlemler } & \multicolumn{6}{|c|}{ Derinlik kademeleri (cm) } \\
\hline & $0-5$ & $5-15$ & $15-30$ & $30-50$ & $50-70$ & $70-100$ \\
\hline \multicolumn{7}{|c|}{ Hacim ağırlıkları $\left(\mathrm{g} / \mathrm{cm}^{3}\right)$} \\
\hline 1NÇm & $0,93 \pm 0,12^{\mathrm{a}}$ & $1,03 \pm 0,08^{\mathrm{a}}$ & $1,07 \pm 0,09^{\mathrm{ab}}$ & $1,01 \pm 0,10^{\mathrm{a}}$ & $1,00 \pm 0,11^{\mathrm{a}}$ & $1,02 \pm 0,10^{\mathrm{a}}$ \\
\hline $2 \mathrm{NÇm}$ & $0,90 \pm 0,15^{\mathrm{a}}$ & $0,99 \pm 0,11^{\mathrm{a}}$ & $1,01 \pm 0,13^{\mathrm{a}}$ & $0,94 \pm 0,18^{\mathrm{a}}$ & $0,93 \pm 0,12^{\mathrm{a}}$ & $0,95 \pm 0,18^{\mathrm{a}}$ \\
\hline YY & $0,86 \pm 0,13^{\mathrm{a}}$ & $0,93 \pm 0,14^{\mathrm{a}}$ & $0,98 \pm 0,13^{\mathrm{a}}$ & $0,93 \pm 0,13^{\mathrm{a}}$ & $0,97 \pm 0,11^{\mathrm{a}}$ & $0,99 \pm 0,11^{\mathrm{a}}$ \\
\hline GY & $0,88 \pm 0,04^{\mathrm{a}}$ & $1,08 \pm 0,31^{\mathrm{a}}$ & $1,18 \pm 0,09^{\mathrm{b}}$ & $1,16 \pm 0,17^{\mathrm{a}}$ & $1,10 \pm 0,14^{\mathrm{a}}$ & $1,07 \pm 0,15^{\mathrm{a}}$ \\
\hline \multicolumn{7}{|c|}{ Kum (\%) } \\
\hline 1NÇm & $23,4 \pm 7,1^{\mathrm{a}}$ & $19,9 \pm 3,8^{\mathrm{a}}$ & $19,1 \pm 4,3^{\mathrm{a}}$ & $15,5 \pm 6,1^{\mathrm{a}}$ & $12,9 \pm 6,6^{\mathrm{a}}$ & $12,3 \pm 6,4^{a}$ \\
\hline $2 \mathrm{NÇm}$ & $35,2 \pm 13,6^{\mathrm{b}}$ & $31,3 \pm 13,4^{b}$ & $25,3 \pm 12,5^{\mathrm{a}}$ & $21,0 \pm 13,9^{\mathrm{a}}$ & $18,9 \pm 15,1^{\mathrm{a}}$ & $18,8 \pm 17,7^{\mathrm{a}}$ \\
\hline YY & $29,5 \pm 6,7^{\mathrm{ab}}$ & $26,4 \pm 7,2^{\mathrm{ab}}$ & $19,1 \pm 7,6^{\mathrm{a}}$ & $16,1 \pm 7,1^{\mathrm{a}}$ & $13,0 \pm 8,1^{\mathrm{a}}$ & $14,1 \pm 8,6^{\mathrm{a}}$ \\
\hline GY & $56,9 \pm 10,0^{\mathrm{c}}$ & $50,3 \pm 15,3^{\mathrm{c}}$ & $51,8 \pm 12,7^{\mathrm{b}}$ & $46,7 \pm 17,9^{\mathrm{b}}$ & $42,7 \pm 15,9^{\mathrm{b}}$ & $38,5 \pm 4,7^{\mathrm{b}}$ \\
\hline \multicolumn{7}{|c|}{ Toz $(\%)$} \\
\hline $1 \mathrm{NÇm}$ & $31,3 \pm 5,2^{b}$ & $28,2 \pm 7,3^{b}$ & $25,2 \pm 8,3^{\mathrm{b}}$ & $21,8 \pm 8,3^{c}$ & $21,1 \pm 9,6^{c}$ & $18,7 \pm 8,2^{b}$ \\
\hline 2NÇm & $18,7 \pm 5,9^{\mathrm{a}}$ & $16,8 \pm 5,4^{\mathrm{a}}$ & $11,0 \pm 6,8^{\mathrm{a}}$ & $9,6 \pm 5,7^{\mathrm{a}}$ & $5,1 \pm 3,6^{\mathrm{a}}$ & $8,4 \pm 5,3^{\mathrm{a}}$ \\
\hline YY & $27,0 \pm 7,1^{\mathrm{b}}$ & $27,5 \pm 7,6^{b}$ & $24,5 \pm 8,6^{b}$ & $18,1 \pm 8,4^{\mathrm{bc}}$ & $15,9 \pm 8,1^{\mathrm{bc}}$ & $14,6 \pm 6,4^{\mathrm{ab}}$ \\
\hline GY & $17,5 \pm 4,3^{\mathrm{a}}$ & $17,5 \pm 3,6^{\mathrm{a}}$ & $16,0 \pm 6,8^{\mathrm{a}}$ & $10,9 \pm 6,4^{\mathrm{ab}}$ & $9,8 \pm 7,6^{\mathrm{ab}}$ & $8,8 \pm 7,7^{\mathrm{a}}$ \\
\hline \multicolumn{7}{|c|}{ Kil (\%) } \\
\hline 1NÇm & $45,3 \pm 8,2^{b}$ & $51,9 \pm 8,9^{b}$ & $55,8 \pm 10,2^{\mathrm{b}}$ & $62,7 \pm 12,0^{\mathrm{b}}$ & $66,1 \pm 13,9^{\mathrm{b}}$ & $69,0 \pm 13,4^{\mathrm{a}}$ \\
\hline $2 \mathrm{NÇm}$ & $46,1 \pm 10,7^{b}$ & $51,9 \pm 14,8^{b}$ & $63,7 \pm 14,8^{\mathrm{b}}$ & $69,5 \pm 13,8^{b}$ & $76,0 \pm 16,2^{b}$ & $72,8 \pm 17,7^{\mathrm{a}}$ \\
\hline YY & $43,6 \pm 8,16^{b}$ & $46,1 \pm 6,4^{\mathrm{b}}$ & $56,5 \pm 10,2^{b}$ & $65,8 \pm 10,2^{b}$ & $71,2 \pm 11,3^{b}$ & $71,3 \pm 9,9^{\mathrm{a}}$ \\
\hline GY & $25,5 \pm 8,2^{\mathrm{a}}$ & $32,2 \pm 12,7^{\mathrm{a}}$ & $32,3 \pm 10,1^{\mathrm{a}}$ & $42,4 \pm 19,5^{\mathrm{a}}$ & $47,5 \pm 18,1^{\mathrm{a}}$ & $52,7 \pm 9,7^{\mathrm{a}}$ \\
\hline \multicolumn{7}{|c|}{$\mathrm{pH}$} \\
\hline $1 \mathrm{NÇm}$ & $5,83 \pm 0,48^{\mathrm{ab}}$ & $5,58 \pm 0,59^{a}$ & $5,24 \pm 0,33^{\mathrm{a}}$ & $5,22 \pm 0,28^{\mathrm{ab}}$ & $5,08 \pm 0,21^{\mathrm{ab}}$ & $5,14 \pm 0,20^{\mathrm{a}}$ \\
\hline $2 \mathrm{NÇm}$ & $5,47 \pm 0,36^{\mathrm{a}}$ & $5,27 \pm 0,34^{\mathrm{a}}$ & $5,18 \pm 0,39^{\mathrm{a}}$ & $4,95 \pm 0,21^{\mathrm{a}}$ & $4,92 \pm 0,27^{\mathrm{a}}$ & $5,00 \pm 0,37^{\mathrm{a}}$ \\
\hline YY & $5,54 \pm 0,36^{\mathrm{a}}$ & $5,41 \pm 0,24^{\mathrm{a}}$ & $5,36 \pm 0,20^{\mathrm{a}}$ & $5,27 \pm 0,26^{\mathrm{b}}$ & $5,24 \pm 0,24^{b}$ & $5,25 \pm 0,38^{a}$ \\
\hline GY & $6,13 \pm 0,37^{b}$ & $5,49 \pm 0,34^{\mathrm{a}}$ & $5,45 \pm 0,56^{\mathrm{a}}$ & $5,14 \pm 0,31^{\mathrm{ab}}$ & $5,04 \pm 0,11^{\mathrm{ab}}$ & $5,02 \pm 0,02^{\mathrm{a}}$ \\
\hline \multicolumn{7}{|c|}{ Elektriksel iletkenlik $(\mu \mathrm{S} / \mathrm{cm})^{*}$} \\
\hline $1 \mathrm{NÇm}$ & $85 \pm 90^{\mathrm{a}}$ & $152 \pm 299^{\mathrm{a}}$ & $57 \pm 11^{\mathrm{b}}$ & $50 \pm 9^{\mathrm{b}}$ & $48 \pm 9^{b}$ & $44 \pm 84^{b}$ \\
\hline $2 \mathrm{NÇm}$ & $59 \pm 40^{\mathrm{a}}$ & $36 \pm 24^{\mathrm{a}}$ & $27 \pm 12^{\mathrm{a}}$ & $27 \pm 14^{\mathrm{a}}$ & $23 \pm 14^{\mathrm{ab}}$ & $26 \pm 14^{\mathrm{a}}$ \\
\hline YY & $99 \pm 79^{\mathrm{a}}$ & $68 \pm 62^{\mathrm{a}}$ & $40 \pm 30^{\mathrm{ab}}$ & $35 \pm 21^{\mathrm{a}}$ & $31 \pm 17^{\mathrm{ab}}$ & $35 \pm 20^{\mathrm{ab}}$ \\
\hline GY & $120 \pm 27^{\mathrm{a}}$ & $80 \pm 69^{\mathrm{a}}$ & $138 \pm 144^{\mathrm{b}}$ & $95 \pm 104^{b}$ & $38 \pm 15^{\mathrm{b}}$ & $30 \pm 0^{\mathrm{a}}$ \\
\hline
\end{tabular}

Sütunlarda aynı harf ile gösterilen değerler arasında istatistiksel önemde fark bulunmamaktadır $(\mathrm{p}>0,05)$

*Non-parametrik testlerden Kruskal Wallis ile değerlendirilmiştir.

1NÇm: birinci nesil sahil çamı, 2NÇm: ikinci nesil sahil çamı, YY: yaşlı yapraklı, GY: genç yapraklı

\section{4. Ölü örtü karbon ve besin maddesi}

Yaprak+çürüntü tabakalarındaki istatiksel önemde farklılık gösteren organik karbon yüzdesi, ibreli işlem gruplarında yapraklılara göre daha fazla; azot yüzdesi ise daha düşük değerde kaydedilmiştir. Söz konusu durum $\mathrm{C} / \mathrm{N}$ oranında da geçerli olmuştur (Tablo 6).

Diğer besin maddelerinden sadece değiştirilebilir $\mathrm{Ca}$ ve $\mathrm{Mg}$ içerikleri varyans analizi sonucunda farklı gruplara ayrılmıştır. Buna göre ayrı bir grupta yer alan GY alanları yüksek değerlere sahiptir. Yine aynı tabloda humus tabakasının, karbon yüz- desi ve alınabilir fosfor konsantrasyonu dışındaki değişkenlerin hepsinde istatiksel önemde farklılıklar görülmüştür (Tablo 6).

Ölü örtünün toplam değerlerinde, $1 \mathrm{NÇm} \mathrm{ve} \mathrm{YY}$ alanlarındaki Ca ve $\mathrm{Mg}$ toplam miktarları istatistik analiz sonucuna göre aynı grupta yer alarak daha düşük değerlerde olduğu ortaya konmuştur. Tablo 6'da C, N ve P'nin toplamdaki ortalamalarında $1 \mathrm{NÇm}$ alanları öne çıkmış ve 2. rotasyon, toplam karbon miktarında istatiksel düzeyde ikinci sırada yer almıştır. Potasyumda ise işlem grupları arasında anlamlı farklılıklar saptanmamıştır (Tablo 7). 
Tablo 4. Topraklardaki organik karbon ve bazı besin maddesi konsantrasyonları (Ortalama \pm Standart sapma) Table 4. Organic carbon and some nutrient concentrations in the soils (Mean \pm Standard deviation)

\begin{tabular}{|c|c|c|c|c|c|c|}
\hline \multirow{2}{*}{ İşlemler } & \multicolumn{6}{|c|}{ Derinlik kademeleri (cm) } \\
\hline & $0-5$ & $5-15$ & $15-30$ & $30-50$ & $50-70$ & $70-100$ \\
\hline \multicolumn{7}{|c|}{ Organik karbon (\%) } \\
\hline $1 \mathrm{NÇm}$ & $3,45 \pm 2,56^{\mathrm{a}}$ & $1,44 \pm 0,65^{\mathrm{a}}$ & $0,79 \pm 0,21^{\mathrm{a}}$ & $0,50 \pm 0,10^{\mathrm{a}}$ & $0,38 \pm 0,10^{\mathrm{a}}$ & $0,32 \pm 0,06^{\mathrm{a}}$ \\
\hline $2 \mathrm{NÇm}$ & $3,63 \pm 1,79^{\mathrm{a}}$ & $1,89 \pm 0,65^{\mathrm{a}}$ & $1,23 \pm 0,47^{\mathrm{a}}$ & $0,82 \pm 0,26^{\mathrm{b}}$ & $0,64 \pm 0,18^{\mathrm{c}}$ & $0,50 \pm 0,14^{\mathrm{c}}$ \\
\hline YY & $2,95 \pm 1,40^{\mathrm{a}}$ & $1,84 \pm 1,58^{\mathrm{a}}$ & $1,08 \pm 0,85^{\mathrm{a}}$ & $0,67 \pm 0,26^{\mathrm{ab}}$ & $0,48 \pm 0,11^{\mathrm{ab}}$ & $0,38 \pm 0,10^{\mathrm{ab}}$ \\
\hline GY & $5,79 \pm 0,94^{\mathrm{a}}$ & $2,38 \pm 2,20^{\mathrm{a}}$ & $1,34 \pm 1,00^{\mathrm{a}}$ & $0,80 \pm 0,47^{\mathrm{ab}}$ & $0,56 \pm 0,19^{\mathrm{bc}}$ & $0,48 \pm 0,11^{\mathrm{bc}}$ \\
\hline \multicolumn{7}{|c|}{ Toplam azot $(\%)^{*}$} \\
\hline 1NÇm & $0,16 \pm 0,07^{\mathrm{a}}$ & $0,12 \pm 0,05^{\mathrm{a}}$ & $0,11 \pm 0,06^{\mathrm{a}}$ & $0,11 \pm 0,07^{\mathrm{a}}$ & $0,12 \pm 0,07^{\mathrm{a}}$ & $0,08 \pm 0,05^{\mathrm{a}}$ \\
\hline 2NÇm & $0,19 \pm 0,02^{\mathrm{a}}$ & $0,18 \pm 0,12^{\mathrm{ab}}$ & $0,18 \pm 0,01^{\mathrm{b}}$ & $0,17 \pm 0,01^{\mathrm{b}}$ & $0,17 \pm 0,01^{\mathrm{ab}}$ & $0,17 \pm 0,01^{\mathrm{b}}$ \\
\hline YY & $0,18 \pm 0,04^{\mathrm{a}}$ & $0,15 \pm 0,07^{\mathrm{ab}}$ & $0,12 \pm 0,05^{\mathrm{a}}$ & $0,11 \pm 0,06^{\mathrm{a}}$ & $0,11 \pm 0,06^{\mathrm{a}}$ & $0,09 \pm 0,06^{\mathrm{a}}$ \\
\hline GY & $0,25 \pm 0,03^{\mathrm{b}}$ & $0,21 \pm 0,04^{b}$ & $0,21 \pm 0,04^{\mathrm{c}}$ & $0,19 \pm 0,01^{\mathrm{c}}$ & $0,19 \pm 0,01^{\mathrm{b}}$ & $0,19 \pm 0,01^{\mathrm{b}}$ \\
\hline \multicolumn{7}{|c|}{ Alınabilir fosfor $(\mathrm{mg} / \mathrm{kg})$} \\
\hline $1 \mathrm{NÇm}$ & $4,2 \pm 4,1^{\mathrm{a}}$ & $3,9 \pm 4,4^{\mathrm{a}}$ & $2,6 \pm 3,2^{\mathrm{a}}$ & $0,9 \pm 0,5^{\mathrm{a}}$ & $1,71 \pm 3,21^{\mathrm{a}}$ & $3,38 \pm 7,33^{\mathrm{a}}$ \\
\hline $2 \mathrm{NÇm}$ & $1,7 \pm 3,3^{\mathrm{a}}$ & $1,2 \pm 1,0^{\mathrm{a}}$ & $0,9 \pm 0,5^{\mathrm{a}}$ & $0,9 \pm 0,7^{\mathrm{a}}$ & $0,50 \pm 0,33^{\mathrm{a}}$ & $0,47 \pm 0,35^{\mathrm{a}}$ \\
\hline YY & $3,8 \pm 4,9^{\mathrm{a}}$ & $3,0 \pm 2,6^{\mathrm{a}}$ & $3,5 \pm 3,8^{\mathrm{a}}$ & $3,2 \pm 3,5^{\mathrm{a}}$ & $0,94 \pm 0,94^{\mathrm{a}}$ & $1,34 \pm 1,66^{\mathrm{a}}$ \\
\hline GY & $2,7 \pm 2,0^{\mathrm{a}}$ & $2,3 \pm 3,1^{\mathrm{a}}$ & $0,8 \pm 0,4^{\mathrm{a}}$ & $0,5 \pm 0,3^{\mathrm{a}}$ & $0,42 \pm 0,29^{\mathrm{a}}$ & $0,43 \pm 0,26^{\mathrm{a}}$ \\
\hline \multicolumn{7}{|c|}{ Değiştirilebilir potasyum $(\mathrm{mg} / \mathrm{kg})$} \\
\hline 1NÇm & $134,4 \pm 67,2^{\mathrm{a}}$ & $105,7 \pm 91,5^{\mathrm{a}}$ & $71,8 \pm 42,5^{\mathrm{a}}$ & $69,9 \pm 41,0^{\mathrm{a}}$ & $65,9 \pm 32,0^{\mathrm{a}}$ & $66,3 \pm 27,5^{\mathrm{a}}$ \\
\hline $2 \mathrm{NÇm}$ & $110,7 \pm 69,3^{\mathrm{a}}$ & $79,4 \pm 37,5^{\mathrm{a}}$ & $59,0 \pm 29,2^{\mathrm{a}}$ & $65,3 \pm 34,8^{\mathrm{a}}$ & $68,2 \pm 32,7^{\mathrm{a}}$ & $72,5 \pm 41,7^{\mathrm{a}}$ \\
\hline YY & $122,9 \pm 84,0^{\mathrm{a}}$ & $82,9 \pm 58,8^{\mathrm{a}}$ & $79,8 \pm 57,3^{\mathrm{a}}$ & $85,5 \pm 48,8^{\mathrm{a}}$ & $86,8 \pm 44,9^{\mathrm{a}}$ & $78,3 \pm 35,2^{\mathrm{a}}$ \\
\hline GY & $146,6 \pm 38,3^{\mathrm{a}}$ & $104,7 \pm 45,9^{\mathrm{a}}$ & $76,6 \pm 25,5^{\mathrm{a}}$ & $59,4 \pm 19,5^{\mathrm{a}}$ & $52,8 \pm 17,2^{\mathrm{a}}$ & $47,0 \pm 8,4^{\mathrm{a}}$ \\
\hline \multicolumn{7}{|c|}{ Değiştirilebilir kalsiyum $(\mathrm{mg} / \mathrm{kg})$} \\
\hline $1 \mathrm{NÇm}$ & $646,8 \pm 298,8^{a}$ & $420,7 \pm 202,4^{a}$ & $377,5 \pm 212,8^{\mathrm{a}}$ & $358,8 \pm 171,5^{\mathrm{a}}$ & $406,7 \pm 156,1^{\mathrm{a}}$ & $456,8 \pm 191,2^{\mathrm{a}}$ \\
\hline $2 \mathrm{NÇm}$ & $636,4 \pm 294,4^{\mathrm{a}}$ & $662,6 \pm 351,2^{\mathrm{a}}$ & $590,3 \pm 338,6^{\mathrm{a}}$ & $668,0 \pm 345,2^{\mathrm{a}}$ & $732,8 \pm 460,6^{\mathrm{a}}$ & $751,8 \pm 493,0^{\mathrm{a}}$ \\
\hline YY & $589,0 \pm 435,7^{\mathrm{a}}$ & $482,0 \pm 411,9^{\mathrm{a}}$ & $501,8 \pm 375,3^{\mathrm{a}}$ & $579,7 \pm 396,1^{\mathrm{a}}$ & $609,4 \pm 412,6^{\mathrm{a}}$ & $656,4 \pm 449,3^{\mathrm{a}}$ \\
\hline GY & $822,3 \pm 124,3^{\mathrm{a}}$ & $504,3 \pm 408,8^{\mathrm{a}}$ & $369,8 \pm 217,5^{\mathrm{a}}$ & $311,0 \pm 184,0^{\text {a }}$ & $290,3 \pm 177,6^{\mathrm{a}}$ & $314,5 \pm 135,6^{\mathrm{a}}$ \\
\hline \multicolumn{7}{|c|}{ Değiştirilebilir magnezyum (mg/kg)* } \\
\hline $1 \mathrm{NÇm}$ & $92,5 \pm 5,0^{\mathrm{a}}$ & $86,2 \pm 7,9^{\mathrm{a}}$ & $83,4 \pm 7,7^{\mathrm{a}}$ & $88,7 \pm 11,4^{\mathrm{a}}$ & $92,3 \pm 8,8^{a}$ & $93,6 \pm 7,5^{\mathrm{a}}$ \\
\hline $2 \mathrm{NÇm}$ & $90,7 \pm 14,8^{\mathrm{a}}$ & $91,5 \pm 8,6^{\mathrm{a}}$ & $92,3 \pm 8,1^{\mathrm{a}}$ & $96,6 \pm 3,3^{a}$ & $96,9 \pm 6,2^{\mathrm{a}}$ & $87,1 \pm 20,6^{\mathrm{a}}$ \\
\hline YY & $85,8 \pm 13,9^{\mathrm{a}}$ & $80,6 \pm 20,4^{a}$ & $91,4 \pm 10,6^{\mathrm{a}}$ & $97,3 \pm 5,3^{\mathrm{a}}$ & $97,2 \pm 4,5^{\mathrm{a}}$ & $96,6 \pm 3,6^{\mathrm{a}}$ \\
\hline GY & $96,5 \pm 1,2^{\mathrm{a}}$ & $88,9 \pm 5,7^{\mathrm{a}}$ & $82,8 \pm 27,4^{\mathrm{a}}$ & $82,8 \pm 20,5^{\mathrm{a}}$ & $86,2 \pm 15,3^{\mathrm{a}}$ & $91,7 \pm 12,9^{\mathrm{a}}$ \\
\hline
\end{tabular}

Sütunlarda aynı harf ile gösterilen değerler arasında istatistiksel önemde fark bulunmamaktadır $(\mathrm{p}>0,05)$.

*Non-parametrik testlerden Kruskal Wallis ile değerlendirilmiştir

1NÇm:birinci nesil sahil çamı, 2NÇm: ikinci nesil sahil çamı, YY: yaşlı yapraklı, GY: genç yapraklı

\section{5. Ölü örtü karbon ve besin maddesi stokları}

Yaprak+çürüntü tabakalarında; en fazla karbon stoku ibrelilerde bulunarak ve iki ayrı kümede toplanmakta olup, 2NÇm meşceresinde 1NÇm'den düşük çıkmıştır (Tablo 7). Yapraklı meşçereler aynı kümede yer alarak istatiksel önemde ibrelilere nazaran daha az karbon stoku içermiştir. Tablo 7'de görüldüğü üzere N ve P stoklarında, meşçere grupları arasında anlamlı bir farklılık bulunmuş ve yapraklı meşcerelerde ibrelilere nispeten söz konusu besin maddeleri azalmıştır. 1NÇm ile GY meşcerelerinde $\mathrm{Ca}$ ve $\mathrm{Mg}$ elementlerinin (Tablo 7), diğer 2 gruba kıyasla istatistiksel anlam düzeyinde farklılık göstererek daha fazla depolandığı tespit edilmiştir. Humus tabakalarında depo edilen karbon ve diğer besin elementleri $1 \mathrm{NÇm}$ ve GY meşcerelerde daha yüksek bulunmuştur.
Ölü örtünün toplam değerlerinde (Tablo 7), 1NÇm ve YY örnek alanlarındaki Ca ve Mg toplam miktarları istatistik analiz sonucuna göre aynı grupta yer alarak, daha düşük değerlerde olduğu ortaya konmuştur. Aynı tabloda C, N, P'nin toplamdaki ortalamalarında $1 \mathrm{NÇm}$ örnek alanı öne çıkmakta ve 2. rotasyon, toplam karbon miktarında istatiksel düzeyde ikinci sırada yer almaktadır. Toplam potasyumda ise işlem grupları arasında anlamlı farklılıklar saptanmamıştır (Tablo 7).

\section{Tartışma ve Sonuç}

\section{1. Ölü örtü miktarı}

Çalışmada varılan en belirgin sonuç, işlem grupları arasında ölü örtü miktarlarındaki farklılıklar olmuştur. Ölü örtü miktarı genç ve yaşlı yapraklı baltalıklarda sirasiyla 8,9 ve 7,1 t/ha olarak bulun- 
muştur. Tolunay ve Çömez (2008), Türkiye'deki yapraklı ormanlardaki ortalama ölü örtü miktarının $8,2 \mathrm{t} /$ ha olduğunu açıklamakta olup çalışmamızda bulunan değerlerle paralellik göstermektedir. Makineci ve ark. (2011) tarafından Trakya'daki meşe baltalıklarında ölü örtü miktarları a çağındaki meşcerelerde 4,3 t/ha, b çağındaki meşcerelerde $6,4 \mathrm{t} /$ ha ve c çağındaki meşcerelerde 10,6 t/ha olarak belirlenmiştir. Ancak Zengin (1998) tarafından Kerpe'de doğal yapraklı ormanlarda ortalama ölü örtü miktarı 16,48 t/ha olarak verilmekte olup çalışmamızdaki değerlerden yüksektir. Aynı bölgedeki yapraklı meşcerelerin ölü örtü miktarları arasındaki farklılığın örnekleme zamanından kaynaklanmış olabileceği gibi; sıklık, meşcere yaşı ve silvikültürel uygulamaların farklı olmasından kaynaklanabileceği düşünülmektedir. Zengin (1998) ölü örtü örnekleme zamanını belirtmemiş olup, çalışmamızda ölü örtü örnekleri sonbaharda yaprak dökümü başlamadan önce alınmıştır. Yaşlı yapraklı meşcere- lerin tıraşlanarak genç baltalıkların oluşturulduğu alanlarda 10 yıl sonunda toplam ölü örtü miktarları genç meşcerelerde az da olsa yüksek bulunmuştur. $\mathrm{Bu}$ durum tıraşlama sonrasında kesim artıklarının sahada bırakılmasından kaynaklanmış olabilir (Wall, 2008; Wall ve Hytönen, 2011). Yine tıraşlamadan sonra sahadaki ekolojik koşullar (1şık, sıcaklık, nem, yağış vb.) ile toprak özellikleri ( $\mathrm{pH}$, toprak nemi, besin durumu vb.) değiştiği için ölü örtünün ayrışma şartları da değişebilmektedir (Jandl ve ark., 2007). Kesim artıkları aynı zamanda ölü örtü kalitesini değiştirerek ölü örtü miktarını arttırabilmektedir. Özellikle kesim artıklarının sahada bırakıldığı durumlarda lignin içeriği daha yüksek olan ve daha geç ayrışan odunsu artık miktarı da fazla olabilmektedir (Palviainen ve ark., 2004). Tiraşlamalardan sonra ağaçların gelişmesi ve kapalılığın oluşması ile birlikte ekolojik koşullar tıraşlama öncesine yaklaşmakta ve yaprak dökümü ile birlikte de ölü örtü miktarı aralama öncesine gelebilmektedir.

Tablo 5. Topraklardaki organik karbon ve bazı besin maddesi stokları (Ortalama \pm Standart sapma) Table 5. Organic carbon and some nutrient stocks in the soils (Mean \pm Standard deviation)

\begin{tabular}{|c|c|c|c|c|c|c|c|}
\hline \multirow{2}{*}{ İşlemler } & \multicolumn{6}{|c|}{ Derinlik kademeleri $(\mathrm{cm})$} & \multirow{2}{*}{ Toplam } \\
\hline & $0-5$ & $5-15$ & $15-30$ & $30-50$ & $50-70$ & $70-100$ & \\
\hline \multicolumn{8}{|c|}{ Toprak organik karbon stoku (t/ha) } \\
\hline $1 \mathrm{NÇm}$ & $13,4 \pm 6,5^{\mathrm{a}}$ & $13,7 \pm 5,3^{\mathrm{a}}$ & $11,7 \pm 2,6^{\mathrm{a}}$ & $9,7 \pm 2,1^{\mathrm{a}}$ & $7,2 \pm 1,6^{\mathrm{a}}$ & $9,3 \pm 1,5^{\mathrm{a}}$ & $65,1 \pm 12,8^{\mathrm{a}}$ \\
\hline 2NÇm & $13,9 \pm 7,1^{\mathrm{a}}$ & $16,6 \pm 5,4^{\mathrm{a}}$ & $16,7 \pm 4,7^{\mathrm{a}}$ & $14,1 \pm 4,8^{\mathrm{a}}$ & $11,0 \pm 3,2^{b}$ & $13,2 \pm 3,1^{\mathrm{b}}$ & $85,5 \pm 20,5^{\mathrm{a}}$ \\
\hline YY & $11,1 \pm 3,8^{\mathrm{a}}$ & $14,8 \pm 9,6^{\mathrm{a}}$ & $14,8 \pm 10,2^{\mathrm{a}}$ & $12,1 \pm 4,6^{\mathrm{a}}$ & $9,0 \pm 2,2^{\mathrm{ab}}$ & $11,0 \pm 3,0^{\mathrm{ab}}$ & $72,8 \pm 28,3^{\mathrm{a}}$ \\
\hline GY & $20,3 \pm 3,5^{\mathrm{a}}$ & $15,6 \pm 8,7^{\mathrm{a}}$ & $17,4 \pm 9,9^{\mathrm{a}}$ & $14,9 \pm 8,4^{\mathrm{a}}$ & $10,9 \pm 3,8^{\mathrm{b}}$ & $13,9 \pm 2,5^{\mathrm{b}}$ & $92,9 \pm 30,3^{\mathrm{a}}$ \\
\hline \multicolumn{8}{|c|}{ Azot stoku (t/ha) } \\
\hline 1NÇm & $0,6 \pm 0,2^{\mathrm{a}}$ & $1,2 \pm 0,5^{\mathrm{a}}$ & $1,7 \pm 0,9^{\mathrm{a}}$ & $2,1 \pm 1,4^{\mathrm{a}}$ & $2,4 \pm 1,6^{\mathrm{a}}$ & $2,3 \pm 1,5^{\mathrm{a}}$ & $15,8 \pm 3,3^{\mathrm{a}}$ \\
\hline 2NÇm & $0,8 \pm 0,1^{\mathrm{a}}$ & $1,6 \pm 0,2^{\mathrm{a}}$ & $2,5 \pm 0,3^{\mathrm{b}}$ & $2,9 \pm 0,5^{\mathrm{ab}}$ & $2,9 \pm 0,4^{\mathrm{a}}$ & $4,5 \pm 0,5^{\mathrm{b}}$ & $20,8 \pm 3,6^{\mathrm{a}}$ \\
\hline YY & $0,7 \pm 0,2^{\mathrm{a}}$ & $1,3 \pm 0,5^{\mathrm{a}}$ & $1,6 \pm 0,6^{\mathrm{a}}$ & $2,0 \pm 1,3^{\mathrm{a}}$ & $2,1 \pm 1,4^{\mathrm{a}}$ & $2,7 \pm 2,0^{\mathrm{a}}$ & $15,9 \pm 7,9^{\mathrm{a}}$ \\
\hline GY & $0,9 \pm 0,1^{\mathrm{a}}$ & $1,7 \pm 0,4^{\mathrm{a}}$ & $2,9 \pm 0,6^{\mathrm{b}}$ & $3,5 \pm 0,6^{\mathrm{b}}$ & $3,7 \pm 0,1^{\mathrm{a}}$ & $5,7 \pm 1,1^{\mathrm{b}}$ & $20,8 \pm 2,5^{\mathrm{a}}$ \\
\hline \multicolumn{8}{|c|}{ Alınabilir fosfor stoku (kg/ha) } \\
\hline 1NÇm & $1,9 \pm 2,1^{b}$ & $4,0 \pm 4,6^{\mathrm{a}}$ & $4,1 \pm 5,1^{\mathrm{a}}$ & $1,8 \pm 0,9^{\mathrm{ab}}$ & $3,3 \pm 6,2^{\mathrm{a}}$ & $10,4 \pm 22,9^{\mathrm{a}}$ & $25,5 \pm 25,4^{b}$ \\
\hline 2NÇm & $0,7 \pm 1,4^{\mathrm{a}}$ & $1,2 \pm 1,1^{\mathrm{a}}$ & $1,2 \pm 0,9^{\mathrm{a}}$ & $1,7 \pm 1,5^{\mathrm{ab}}$ & $0,9 \pm 0,5^{\mathrm{a}}$ & $1,2 \pm 0,9^{\mathrm{a}}$ & $6,8 \pm 3,0^{\mathrm{a}}$ \\
\hline YY & $1,5 \pm 2,1^{\mathrm{ab}}$ & $2,7 \pm 2,5^{\mathrm{a}}$ & $5,4 \pm 5,9^{\mathrm{a}}$ & $6,2 \pm 7,3^{b}$ & $1,8 \pm 1,9^{\mathrm{a}}$ & $3,9 \pm 4,6^{\mathrm{a}}$ & $21,6 \pm 11,4^{b}$ \\
\hline GY & $0,9 \pm 0,7^{\mathrm{ab}}$ & $1,4 \pm 1,4^{\mathrm{a}}$ & $1,1 \pm 0,4^{\mathrm{a}}$ & $0,9 \pm 0,4^{\mathrm{a}}$ & $0,8 \pm 0,6^{\mathrm{a}}$ & $1,2 \pm 0,5^{\mathrm{a}}$ & $6,2 \pm 2,2^{\mathrm{a}}$ \\
\hline \multicolumn{8}{|c|}{ Değiştirilebilir potasyum stoku (kg/ha) } \\
\hline $1 \mathrm{NÇm}$ & $57,9 \pm 30,4^{\mathrm{a}}$ & $102,5 \pm 86,1^{\mathrm{a}}$ & $109,9 \pm 67,6^{\mathrm{a}}$ & $135,9 \pm 78,8^{\mathrm{a}}$ & $127,5 \pm 62,9^{\mathrm{a}}$ & $197,4 \pm 87,2^{\mathrm{a}}$ & $731,1 \pm 390,7^{\mathrm{a}}$ \\
\hline 2NÇm & $42,2 \pm 25,5^{\mathrm{a}}$ & $70,9 \pm 32,8^{\mathrm{a}}$ & $82,6 \pm 38,4^{\mathrm{a}}$ & $112,8 \pm 61,4^{\mathrm{a}}$ & $117,9 \pm 56,2^{\mathrm{a}}$ & $185,9 \pm 97,5^{\mathrm{a}}$ & $612,3 \pm 274,6^{\mathrm{a}}$ \\
\hline YY & $47,8 \pm 32,8^{\mathrm{a}}$ & $69,1 \pm 45,1^{\mathrm{a}}$ & $109,6 \pm 71,9^{\mathrm{a}}$ & $151,2 \pm 75,7^{\mathrm{a}}$ & $160,4 \pm 70,7^{\mathrm{a}}$ & $222,8 \pm 84,2^{\mathrm{a}}$ & $760,9 \pm 360,8^{a}$ \\
\hline GY & $52,2 \pm 16,6^{\mathrm{a}}$ & $78,5 \pm 14,5^{\mathrm{a}}$ & $107,0 \pm 41,9^{\mathrm{a}}$ & $111,4 \pm 48,6^{\mathrm{a}}$ & $102,3 \pm 38,3^{\mathrm{a}}$ & $138,9 \pm 41,1^{\mathrm{a}}$ & $590,3 \pm 188,2^{\text {a }}$ \\
\hline \multicolumn{8}{|c|}{ Değiştirilebilir kalsiyum stoku (kg/ha) } \\
\hline 1NÇm & $266 \pm 69^{\mathrm{a}}$ & $406 \pm 182^{a}$ & $557 \pm 281^{\mathrm{a}}$ & $693 \pm 335^{\mathrm{a}}$ & $768 \pm 262^{a}$ & $1325 \pm 506^{\mathrm{a}}$ & $4015 \pm 1379^{\mathrm{a}}$ \\
\hline 2NÇm & $242 \pm 112^{\mathrm{a}}$ & $590 \pm 319^{a}$ & $825 \pm 484^{\mathrm{a}}$ & $1174 \pm 696^{\mathrm{a}}$ & $1295 \pm 8242^{\mathrm{a}}$ & $1982 \pm 1296^{\mathrm{a}}$ & $6109 \pm 3590^{\mathrm{a}}$ \\
\hline YY & $219 \pm 140^{\mathrm{a}}$ & $387 \pm 291^{\mathrm{a}}$ & $679 \pm 463^{a}$ & $1012 \pm 639^{\mathrm{a}}$ & $1150 \pm 820^{\mathrm{a}}$ & $1855 \pm 1223^{\mathrm{a}}$ & $5303 \pm 3420^{\mathrm{a}}$ \\
\hline GY & $291 \pm 60,2^{\mathrm{a}}$ & $314 \pm 176^{\mathrm{a}}$ & $518 \pm 267^{\mathrm{a}}$ & $612 \pm 449^{\mathrm{a}}$ & $571 \pm 384^{\mathrm{a}}$ & $913 \pm 455^{\mathrm{a}}$ & $3253 \pm 1290^{\mathrm{a}}$ \\
\hline \multicolumn{8}{|c|}{ Değiștirilebilir magnezyum stoku (kg/ha) } \\
\hline 1NÇm & $40,1 \pm 6,2^{\mathrm{a}}$ & $84,2 \pm 10,3^{\mathrm{a}}$ & $125,9 \pm 20,5^{\mathrm{a}}$ & $172,3 \pm 34,3^{\mathrm{a}}$ & $177,4 \pm 24,5^{\mathrm{a}}$ & $276,7 \pm 34,0^{b}$ & $876,6 \pm 102,3^{a}$ \\
\hline 2NÇm & $35,3 \pm 6,6^{\mathrm{a}}$ & $81,8 \pm 14,2^{\mathrm{a}}$ & $129,9 \pm 23,7^{\mathrm{a}}$ & $167,4 \pm 38,4^{\mathrm{a}}$ & $167,9 \pm 25,2^{\mathrm{a}}$ & $228,9 \pm 53,3^{\mathrm{a}}$ & $811,5 \pm 119,6^{\mathrm{a}}$ \\
\hline YY & $33,9 \pm 7,1^{\mathrm{a}}$ & $69,2 \pm 14,9^{\mathrm{a}}$ & $129,5 \pm 16,7^{\mathrm{a}}$ & $176,1 \pm 15,6^{\mathrm{a}}$ & $183,5 \pm 14,0^{\mathrm{a}}$ & $278,9 \pm 23,3^{b}$ & $871,1 \pm 52,0^{\mathrm{a}}$ \\
\hline GY & $34,0 \pm 3,7^{\mathrm{a}}$ & $74,5 \pm 25,1^{\mathrm{a}}$ & $121,2 \pm 58,3^{\mathrm{a}}$ & $156,3 \pm 60,{ }^{4} \mathrm{a}$ & $166,2 \pm 37,5^{\mathrm{a}}$ & $266,6 \pm 45,9^{\mathrm{ab}}$ & $818,7 \pm 220,8^{\mathrm{a}}$ \\
\hline
\end{tabular}

Sütunlarda aynı harf ile gösterilen değerler arasında istatistiksel önemde fark bulunmamaktadır $(\mathrm{p}>0,05)$.

1NÇm:birinci nesil sahil çamı, 2NÇm: ikinci nesil sahil çamı, YY: yaşlı yapraklı, GY: genç yapraklı 
Tablo 6. Yaprak+çürüntü ve humus tabakalarının karbon ve besin maddesi konsantrasyonları (Ort. \pm Standart sapma)

Table 6. Carbon and nutrient concentrations of litter+fermantation and humus layers (Mean \pm Standard deviation)

\begin{tabular}{|c|c|c|c|c|c|c|c|}
\hline İşlemler & $\mathrm{C}(\%)$ & $\mathrm{N}(\%)$ & $\mathrm{C} / \mathrm{N}^{*}$ & $\mathrm{P}(\mathrm{mg} / \mathrm{kg})$ & $\mathrm{K}(\mathrm{mg} / \mathrm{kg})$ & $\mathrm{Ca}(\mathrm{mg} / \mathrm{kg})$ & $\mathrm{Mg}(\mathrm{mg} / \mathrm{kg})$ \\
\hline \multicolumn{8}{|c|}{ Yaprak+çürüntü tabakası } \\
\hline 1NÇm & $45,78 \pm 1,90^{\mathrm{b}}$ & $1,09 \pm 0,81^{\mathrm{a}}$ & $42,13^{\mathrm{b}}$ & $1,89 \pm 0,44^{\mathrm{a}}$ & $7,24 \pm 5,31^{\mathrm{a}}$ & $30,71 \pm 7,68^{\mathrm{a}}$ & $5,03 \pm 2,46^{\mathrm{a}}$ \\
\hline $2 \mathrm{NÇm}$ & $44,58 \pm 4,71^{\text {b }}$ & $1,24 \pm 0,18^{\mathrm{a}}$ & $36,86^{\mathrm{b}}$ & $2,00 \pm 0,52^{\mathrm{a}}$ & $7,90 \pm 3,61^{\mathrm{a}}$ & $23,54 \pm 12,73^{\mathrm{a}}$ & $6,36 \pm 3,38^{\mathrm{a}}$ \\
\hline YY & $42,24 \pm 3,60^{\mathrm{ab}}$ & $1,86 \pm 0,18^{b}$ & $22,95^{\mathrm{a}}$ & $1,75 \pm 0,40^{\mathrm{a}}$ & $10,15 \pm 0,74^{\mathrm{a}}$ & $26,48 \pm 12,38^{\mathrm{a}}$ & $6,53 \pm 2,19^{\mathrm{a}}$ \\
\hline GY & $40,15 \pm 1,34^{\mathrm{a}}$ & $1,85 \pm 0,14^{\mathrm{b}}$ & $21,76^{\mathrm{a}}$ & $1,82 \pm 0,31^{\mathrm{a}}$ & $11,53 \pm 1,96^{\mathrm{a}}$ & $58,76 \pm 10,57^{\mathrm{b}}$ & $14,37 \pm 2,43^{\mathrm{b}}$ \\
\hline \multicolumn{8}{|c|}{ Humus tabakasi } \\
\hline $1 \mathrm{NÇm}$ & $34,00 \pm 3,47^{\mathrm{a}}$ & $1,41 \pm 0,17^{\mathrm{a}}$ & $24,43 \pm 3,42^{\mathrm{c}}$ & $1,79 \pm 0,36^{\mathrm{a}}$ & $10,38 \pm 3,32^{\mathrm{a}}$ & $7,72 \pm 3,94^{\mathrm{a}}$ & $4,35 \pm 1,82^{\mathrm{a}}$ \\
\hline $2 \mathrm{NÇm}$ & $30,35 \pm 7,37^{\mathrm{a}}$ & $1,50 \pm 0,28^{\mathrm{a}}$ & $20,74 \pm 7,06^{\mathrm{bc}}$ & $1,76 \pm 0,28^{\mathrm{a}}$ & $10,85 \pm 2,79^{a}$ & $8,40 \pm 13,64^{\mathrm{ab}}$ & $7,31 \pm 4,96^{\mathrm{a}}$ \\
\hline YY & $32,50 \pm 4,19^{\mathrm{a}}$ & $1,90 \pm 0,20^{\mathrm{b}}$ & $17,21 \pm 2,24^{\mathrm{ab}}$ & $1,54 \pm 0,36^{\mathrm{a}}$ & $15,18 \pm 5,32^{\mathrm{b}}$ & $12,42 \pm 6,79^{b}$ & $7,14 \pm 2,85^{\mathrm{a}}$ \\
\hline GY & $26,80 \pm 4,34^{\mathrm{a}}$ & $1,76 \pm 0,21^{\mathrm{b}}$ & $15,19 \pm 0,70^{\mathrm{a}}$ & $1,52 \pm 0,54^{\mathrm{a}}$ & $9,78 \pm 1,12^{\mathrm{a}}$ & $39,46 \pm 27,58^{c}$ & $16,10 \pm 3,91^{\mathrm{b}}$ \\
\hline
\end{tabular}

Sütunlarda aynı harf ile gösterilen değerler arasında istatistiksel önemde fark bulunmamaktadır $(\mathrm{p}>0,05)$.

"Non-parametrik testlerden Kruskal Wallis ile değerlendirilmistir.

1NÇm: birinci nesil sahil çamı, 2NÇm: ikinci nesil sahil çamı, YY: yaşlı yapraklı, GY: genç yapraklı

Tablo 7. Yaprak+çürüntü ve humus tabakasındaki karbon ve besin maddesi stokları (Ortalama \pm Standart sapma)

Table 7. Carbon and nutrient stocks in litter+fermantation and humus layers (Mean \pm Standard deviation)

\begin{tabular}{|c|c|c|c|c|c|c|}
\hline İşlemler & $\mathrm{C}(\mathrm{t} / \mathrm{ha})$ & $\mathrm{N}(\mathrm{t} / \mathrm{ha})$ & $\mathrm{P}(\mathrm{kg} / \mathrm{ha})$ & $\mathrm{K}(\mathrm{kg} / \mathrm{ha})$ & $\mathrm{Ca}(\mathrm{kg} / \mathrm{ha})$ & $\mathrm{Mg}(\mathrm{kg} / \mathrm{ha})$ \\
\hline \multicolumn{7}{|c|}{ Yaprak+çürüntü tabakası } \\
\hline 1NÇm & $6,89 \pm 1,50^{\mathrm{c}}$ & $0,16 \pm 0,04^{\mathrm{b}}$ & $0,03 \pm 0,01^{\mathrm{b}}$ & $0,12 \pm 0,10^{\mathrm{a}}$ & $0,46 \pm 0,14^{\mathrm{c}}$ & $0,08 \pm 0,05^{\mathrm{b}}$ \\
\hline $2 \mathrm{NÇm}$ & $4,62 \pm 0,76^{\mathrm{b}}$ & $0,13 \pm 0,04^{\mathrm{ab}}$ & $0,02 \pm 0,01^{\mathrm{b}}$ & $0,08 \pm 0,05^{\mathrm{a}}$ & $0,24 \pm 0,12^{\mathrm{ab}}$ & $0,07 \pm 0,04^{\mathrm{ab}}$ \\
\hline YY & $2,33 \pm 0,54^{\mathrm{a}}$ & $0,10 \pm 0,04^{\mathrm{a}}$ & $0,01 \pm 0^{\mathrm{a}}$ & $0,06 \pm 0,02^{\mathrm{a}}$ & $0,14 \pm 0,06^{\mathrm{a}}$ & $0,04 \pm 0,02^{\mathrm{a}}$ \\
\hline GY & $2,29 \pm 0,36^{\mathrm{a}}$ & $0,11 \pm 0,02^{\mathrm{a}}$ & $0,01 \pm 0^{\mathrm{a}}$ & $0,07 \pm 0,02^{\mathrm{a}}$ & $0,33 \pm 0,05^{\mathrm{b}}$ & $0,08 \pm 0,02^{\mathrm{b}}$ \\
\hline \multicolumn{7}{|c|}{ Humus tabakası } \\
\hline $1 \mathrm{NÇm}$ & $1,59 \pm 1,09^{c}$ & $0,06 \pm 0,04^{\mathrm{b}}$ & $0,009 \pm 0,007^{\mathrm{b}}$ & $0,05 \pm 0,03^{\mathrm{c}}$ & $0,04 \pm 0,03^{\mathrm{b}}$ & $0,02 \pm 0,02^{\mathrm{b}}$ \\
\hline $2 \mathrm{NÇm}$ & $0,31 \pm 0,26^{\mathrm{a}}$ & $0,01 \pm 0,01^{\mathrm{a}}$ & $0,002 \pm 0,002^{\mathrm{a}}$ & $0,01 \pm 0,01^{\mathrm{a}}$ & $0,01 \pm 0,01^{\mathrm{a}}$ & $0,01 \pm 0,01^{\mathrm{a}}$ \\
\hline YY & $0,49 \pm 0,20^{\mathrm{ab}}$ & $0,03 \pm 0,01^{\mathrm{a}}$ & $0,002 \pm 0,001^{\mathrm{a}}$ & $0,02 \pm 0,01^{\mathrm{ab}}$ & $0,02 \pm 0,01^{\mathrm{b}}$ & $0,01 \pm 0,005^{\mathrm{a}}$ \\
\hline GY & $0,89 \pm 0,26^{\mathrm{bc}}$ & $0,06 \pm 0,02^{\mathrm{b}}$ & $0,005 \pm 0,002^{\mathrm{b}}$ & $0,03 \pm 0,01^{\mathrm{bc}}$ & $0,13 \pm 0,09^{c}$ & $0,05 \pm 0,01^{\mathrm{c}}$ \\
\hline \multicolumn{7}{|c|}{ Toplam } \\
\hline $1 \mathrm{NÇm}$ & $8,48 \pm 2,36^{\mathrm{c}}$ & $0,23 \pm 0,07^{b}$ & $0,04 \pm 0,014^{\mathrm{b}}$ & $0,16 \pm 0,12^{\mathrm{a}}$ & $0,49 \pm 0,15^{\mathrm{b}}$ & $0,10 \pm 0,05^{\mathrm{bc}}$ \\
\hline $2 \mathrm{NÇm}$ & $4,92 \pm 0,98^{\mathrm{b}}$ & $0,15 \pm 0,06^{\mathrm{a}}$ & $0,02 \pm 0,013^{\mathrm{a}}$ & $0,09 \pm 0,05^{\mathrm{a}}$ & $0,25 \pm 0,12^{\mathrm{a}}$ & $0,07 \pm 0,04^{\mathrm{ab}}$ \\
\hline YY & $2,82 \pm 0,69^{\mathrm{a}}$ & $0,13 \pm 0,04^{\mathrm{a}}$ & $0,01 \pm 0,004^{\mathrm{a}}$ & $0,08 \pm 0,03^{\mathrm{a}}$ & $0,16 \pm 0,06^{\mathrm{a}}$ & $0,05 \pm 0,02^{\mathrm{a}}$ \\
\hline GY & $3,17 \pm 0,59^{\mathrm{a}}$ & $0,16 \pm 0,04^{\mathrm{a}}$ & $0,02 \pm 0,004^{\mathrm{a}}$ & $0,10 \pm 0,02^{\mathrm{a}}$ & $0,46 \pm 0,14^{b}$ & $0,13 \pm 0,03^{\mathrm{c}}$ \\
\hline
\end{tabular}

Sütunlarda aynı harf ile gösterilen değerler arasında istatistiksel önemde fark bulunmamaktadır $(\mathrm{p}>0,05)$.

1NÇm: birinci nesil sahil çamı, 2NÇm: ikinci nesil sahil çamı, YY: yaşlı yapraklı, GY: genç yapraklı.

Çalışmamızdaki diğer bir bulgu yapraklı türlerin yerine sahil çamı ile yapılan tür değişiminin ölü örtü miktarını arttırdığıdır. Benzer sonuçlara Türkiye'de yapılan çeşitli çalışmalarda da ulaşılmıştır. Örneğin Zengin (1998) tarafından yine Kerpe'de gerçekleştirilen ve yapraklı türlerin yerine sahil çamı ağaçlandırmasının yapıldığı bir çalışmada ölü örtü miktarı sahil çamı meşcerelerinde 24,5 t/ha, yapraklı meşcerelerde ise $16,5 \mathrm{t}$ /ha olarak belirlenmiş ve sahil çamı meşcerelerinde ölü örtü miktarının arttı̆̆ı ortaya konmuştur. Zengin (1998)'in araştırmasında sahil çamı ağaçlandırmalarında 24,5 t/ ha olarak raporlanan ölü örtü miktarı, çalışmamızda 1. rotasyon döneminin sonundaki 40 yaşlı örnek alanlarda belirlenen 19,7 t/ha ölü örtü miktarından az da olsa yüksektir. Benzer şekilde Scott ve Messina (2010) çam ve yapraklı doğal ormanların Pinus teada ve meşe ormanlarına dönüştürülmesinin ölü örtü üzerindeki etkilerini incelemişler ve ölü örtü miktarlarını Pinus teada ağaçlandırmalarında 18,2 $\mathrm{t} /$ ha, meşe ağaçlandırmalarında ise 9,2 t/ha olarak belirlemişlerdir. Bu durumun, yapraklı türlerin ölü örtülerinin ayrışma hızlarının ibreli türlerden fazla olmasından kaynaklandığı düşünülmektedir (Kantarc1, 2000). Nitekim çalışmamızda ölü örtü C/N oranları yapraklı meşcerelerde ibrelilere göre daha düşüktür. İkinci rotasyon sahil çamı ağaçlandırmalarında 10 yıl sonunda 11,5 t/ha kadar bir ölü örtü birikmiştir. Bu ölü örtü miktarı yapraklı meşcerelerden fazla ancak yaşı sahil çamı ağaçlandırmalarından ise $8 \mathrm{t} /$ ha kadar düşüktür. Tecimen (2005) tarafından Ağaçlı'da (İstanbul, Eyüpsultan) eski maden sahalarının rehabilitasyonunda kullanılan 15 yaşındaki sahil çamı ağaçlandırmalarında ölü örtü miktarlarının 6,42 t/ ha ile 14,32 t/ha arasında değiştiği belirlenmiş ve çalışmamızda bulduğu- 
muz değerlere yakındır. Yaşlı ve genç sahil çamı ağaçlandırmalarında ölü örtü miktarlarının farklı olmasının nedeninin genç sahil çamı ağaçlandırmalarında kapalılığın tam olarak oluşmaması ve bu nedenle döküm miktarının daha az olmasına bağlı olabileceği değerlendirilmektedir. 2NÇm örnek alanlarında ağaçlandırma öncesinde ölü örtünün temizlendiği dikkate alındığında 10 yılda 11,5 t/ha gibi bir ölü örtü birikimi olması sahil çamı ölü örtüsünün geç ayrışmasındandır. Nitekim sahil çamı işlem gruplarının ölü örtülerindeki $\mathrm{C} / \mathrm{N}$ oranları yapraklılardan daha yüksektir. Ayrıca aralarında istatistiksel açıdan önemli bir fark olmasa da 2. rotasyon sahil çamı ağaçlandırmalarının ölü örtü $\mathrm{C} / \mathrm{N}$ oranları 1. rotasyondakilerden düşüktür. $\mathrm{Bu}$ durum, 2. rotasyonda 10 yıl meşcere içine daha fazla 1ş1k, sicaklık ve nem girmesinin ölü örtü ayrışmasını etkilemiş olmasından kaynaklanmış olabilir.

\section{2. Ölü örtü karbon ve besin maddesi stokları}

Ölü örtüdeki karbon ve besin maddesi konsantrasyonları arasında da farklar belirlenmiştir. $\mathrm{Y}+\mathrm{C}$ tabakasında ibreli işlem gruplarının $\mathrm{C}$ konsantrasyonları daha yüksek, buna karşılık \%N değerleri daha düşüktür. $\mathrm{P}$ ve $\mathrm{K}$ içerikleri işlem gruplarına göre farklılık göstermezken, $\mathrm{Ca}$ ve $\mathrm{Mg}$ genç baltalik meşcerelerinde daha fazla bulunmuştur. Humus tabakalarında ise karbon konsantrasyonları arasında fark yokken yapraklı işlem gruplarının azot konsantrasyonları ibrelilere nazaran daha yüksektir. Bu durumun tür farklılığından kaynaklandığ düşünülmektedir. Ölü örtüdeki karbon ve besin maddesi stokları da ölü örtü miktarlarının farklı olmasından kaynaklı olarak değişmektedir ve genel olarak toplam ölü örtü miktarı daha fazla olan 1 . rotasyondaki sahil çamı ölü örtülerinde daha fazladır. Yaşlı sahil çamı ağaçlandırmalarında ortalama 8,48 t/ha olan ölü örtü karbon stokları diğer araştırmalarla karşılaştırıldığında düşük bulunmuştur. Örneğin Ruiz-Peinado ve ark. (2013), İspanya'daki 59 yaşındaki sahil çamı ağaçlandırmalarında ölü örtü karbon stoklarının 24,5-17,04 t/ha arasında değiştiğini belirtmektedirler. Benzer şekilde Durusu kumulunun (İstanbul) üzerindeki sahil çamı ağaçlandırmalarında ölü örtü karbon stoklarının a gelişim çağında 5,69, b gelişim çağında 10,15, c gelişim çağında 14,19 ve cd gelişim çağında 17,72 t/ha olduğu belirlenmiştir (Tolunay ve ark., 2017). Ancak İspanya'daki ağaçlandırmaların Akdeniz iklimi etkisinde bulunması nedeniyle şiddetli yaz kuraklığının yaşanmasının ve Durusu kumul ağaçlandırmasında ise yine kumuldan kaynaklanan kurak şartların ölü örtü ayrışmasını yavaşlatmış olduğu ve bu nedenle ölü örtü miktarının fazla olduğu düşünülmektedir. Yapraklı meşcerelerde GY işlem grubunda 3,17 t/ha olarak hesaplanan ölü örtü karbon stokları Makineci ve ark. (2011) tarafından 3 kapalılıktaki b gelişim çağındaki meşe ormanlarında 2,54 t/ha olarak belirlenen ölü örtü karbon stoklarından az da olsa yüksektir. Ancak yaşlı baltalıklar Makineci ve ark. (2011) tarafından Mc3 meşcere tipi için hesaplanan 4,08 t/ha değerinden düşüktür.

Nave ve ark. (2010), odun üretimi çalışmalarının ölü örtüdeki karbon stoklarını, topraktaki organik karbon stoklarına göre daha fazla etkilediğini belirtmektedir.

\subsection{Toprak organik karbon ve besin maddesi stokları}

Çalışmada yapraklı meşcerelerin tıraşlanarak gençleştirilmesinin ve 2 . nesil sahil çamı ağaçlandırmalarının topraklardaki $\mathrm{C}$ ve $\mathrm{N}$ içerikleri üzerinde istatistiki derecede önemli etkileri olduğu belirlenmiştir. Öncelikle toprakların $\mathrm{C}$ içerikleri değerlendirildiğinde $30 \mathrm{~cm}$ derinlikten sonraki tüm derinlik kademelerinde genç yapraklı ve 2. nesil sahil çamı meşcerelerinde C konsantrasyonları 1. nesil sahil çamı ağaçlandırmalarından yüksektir. Yaşlı yapraklı meşcerelerdeki $\mathrm{C}$ konsantrasyonları ise 1 . nesil sahil çamı ağaçlandırmaları ile genç yapraklı meşcerelerin arasında kalmakta ve istatistiksel olarak bu iki işlem grubuyla da benzerlik göstermektedir. Ayrıca toprak organik karbon (TOK) stoklarının 1. nesil sahil çamı ağaçlandırmalarında yaşlı yapraklı meşcerelere göre \%11 daha düşük olduğu belirlenmiştir. TOK stokları ikinci nesil sahil çamı meşcerelerinde birinci nesile göre $\% 31$, genç yaprakl1 meşcerelerde ise yaşlı yapraklı meşcerelere göre \%28 oranında daha yüksek bulunmasına rağmen bu farklar istatistiksel açıdan önemli çıkmamıştır. Bu durumun örnek alanlar içindeki değişkenliğin fazla olmasından kaynaklandığı düşünülmektedir. Bu değişkenlikte örnek alanlarda geçmişte çok farklı arazi hazırlığı ve toprak işleme yöntemlerinin kullanılmış olması da etkilidir. Özellikle 1. nesil sahil çamı ağaçlandırmalarından seçilen örnek alanların aynı toprak işleme yöntemi uygulanmış alanlardan alınması gerekirken yeterli sayıda örnek alan bulunamadığ 1 için örnekleme mecburen farklı toprak işleme gerçekleştirilen alanlarda yapılmıştır.

Tıraşlama kesim ve ağaçlandırma çalışmalarının toprakların karbon içeriklerine etkisi ile ilgili olarak bu işlemlerin toprak karbon konsantrasyonları ve stoklarını arttırıcı ya da azaltıcı yönde etkileri olduğuna dair çeşitli çalışmalar mevcuttur. Örneğin İtalya'da meşe ve gürgen türlerinden oluşan doğal ormanların kavak dikilerek tür değişimine gi- 
dilmesinin 37 yıl sonunda karbon stoklarında \%40 kadar azalmaya neden olduğu ortaya konmuştur (Ferré ve ark., 2014). Peihua ve ark. (2000) tarafindan 2. rotasyon Larix ağaçlandırmalarında 25 yıl sonunda toprakların organik madde içeriklerinin değişmediği açıklanmaktadır. Clarke ve ark. (2015) toprakların kök sökülmesi ya da toprak işlemesi ile karıştırılmasının topraktaki organik maddenin ayrışmasına neden olabileceğini ya da toprakların sıkışması halinde ise ayrışmanın yavaşlayacağını belirtmektedirler. Yine Clarke ve ark. (2015)'ne göre hasat sonrasında değişen nem ve sıcaklık koşulları, önceki nem koşullarına bağlı olarak organik madde ayrışmasını arttırıcı ya da azaltıcı yönde etki yapabilmektedir. Hasat sonrasında intersepsiyonun ve transpirasyonun azalmasına bağlı olarak toprağa sızan su miktarı artabilmektedir. Bu durum organik maddenin çözünmüş formda toprağın derinlerine taşınması üzerinde etkili olabilmektedir (Nieminen, 2004). Ancak hasat sonrasında toprağa ulaşan su miktarının artmasının toprağın hava kapasitesini azaltması durumunda ise toprak organik maddesinin ayrışmasını yavaşlatabilmektedir (Prescott ve ark., 2000). Nitekim Jandl ve ark. (2007) de toprak neminin, ayrışma üzerindeki önemine dikkat çekerek hasat sonrası arazi hazırlığ yapılan yerlerde toprak içinde kalan kesim artıklarının toprak yüzeyindeki kesim artıklarından fark11 ayrışma ve mineralizasyon koşullarına maruz kaldığını belirtmektedirler. Kerpe Araştırma Ormanında da durgun su oluşumları bulunmaktadır.

Çalışmamızda 2. nesil sahil çamı örnek alanlarında organik karbon ve azot stoklarının yaşlı meşcerelerden istatistiksel açıdan önemli olmasa da yüksek bulunmasının nedeninin hasat sonrasında toprakta kalan kökler olduğu düşünülmektedir. Hem toprakların oldukça killi olması hem de hasat sonrası toprağın nem durumunun artması köklerin ayrışmasını yavaşlatmış olmalıdır. Genç yapraklı meşcerelerdeki karbon ve azot stoklarında da 2. nesil sahil çamı ağaçlandırmalarına benzer bir durum bulunmaktadır. Ancak köklerin sökülmediği genç meşcerelerde topraktaki organik karbon ve azot stoklarının artmasında yüzeydeki kesim artıklarının ayrışması ile oluşan çözünmüş organik karbonun yağış suları ile toprağa karışmasının neden olabileceği yorumu yapılabilir. Nitekim genç yapraklı meşcerelerde özellikle ilk $30 \mathrm{~cm}$ derinlikte organik karbon içerikleri istatistiksel açıdan önemli olmasa da diğer işlem gruplarından yüksektir.

Genç yapraklı meşcerelerin topraktaki azot konsantrasyonları tüm derinlik kademelerinde daha yüksektir. 2. nesil sahil çamı ağaçlandırmalarındaki topraklardaki azot konsantrasyonları da 0-5 cm derinlik kademesi haricinde yaşlı yap- raklı meşcereler ve 1. nesil ağaçlandırmalarından daha fazla ölçülmüş olup, $15-30 \mathrm{~cm}, 30-50 \mathrm{~cm}$ ve $70-100 \mathrm{~cm}$ derinlik kademelerinde bu fark istatiksel açıdan önemlidir. Bu bulgular toprak organik karbon konsantrasyonları ve stokları ile paralellik göstermektedir. Ancak aynı ağaç türü ile yapılan 2. nesil ağaçlandırmalarda ağaçlandırma sonrasında toprakların karbon ve azot stoklarında oluşan farkların zamanla kapanabildiği de belirtilmektedir. Örneğin Peihua ve ark. (2000) 2. nesil Larix ağaçlandırmalarında 25 yıl sonra azot konsantrasyonları 1. nesil ağaçlandırmalarla benzer bulmuştur. Egnell ve ark. (2015) aynı türle yapılan 2. nesil ağaçlandırmalarda kesilen ağaçların kesilen köklerinin temizlenmesi işleminin toprakların $\mathrm{C}$ ve $\mathrm{N}$ içerikleri etkilerine dair farklı bulgulara ulaşılan araştırmalar olduğunu, bu durum üzerinde farklı kök sökme ekipmanları kullanılmasının, kök sökme işlemi ile birlikte toprak işlemenin de yapılıp yapılmamasının, toprakların sıkışıp sıkışmamasının ve toprak işleme derinliğinin etkili olabileceğini açıklamaktadırlar. İşlem gruplarının $1 \mathrm{~m}$ derinlikteki toprak için hesaplanan toplam azot stokları arasındaki farkların istatistiksel açıdan önemli olmadığ 1 belirlenmiştir. Ancak 2. nesil sahil çamı ağaçlandırmalarının 1. nesilden, genç yapraklıların da yaşlı yapraklılardan yaklaşık 5 t/ha kadar daha fazla azot stokuna sahip olduğu dikkat çekmektedir. Bu da genç meşcerelerde yaşlı meşcerelere göre topraktaki azot stoklarının \%31 kadar daha fazla olduğu anlamına gelmektedir. Yaşlı ibreli ve yapraklı meşcerelerin topraktaki azot stokları ise oldukça benzerdir. Bunun kesim artıklarının ayrışmasıyla serbest kalan azotun yıkanarak kilce zengin alt toprak katmanlarında tutulmasının neden olabileceği düşünülmektedir.

Araştırmamızda işlem gruplarının topraklarındaki alınabilir P ile değiştirilebilir K, Mg ve Ca stokları arasında istatistiksel açıdan önemli farklar belirlenememiştir. Ancak Ca stokları hariç genel olarak tıraşlanarak sahil çamı dikilen 2. nesil ağaçlandırmalarda ve yine tıraşlanarak getirilen genç yapraklı meşcerelerde incelenen bitki besin maddesi stokları yaşlı meşcerelere nazaran daha düşüktür. Özellikle fosfor stoklarının 2. nesil sahil çamı ve genç yapraklı meşcerelerde yaşlı meşcerelere göre sırasıyla $\% 73$ ve $\% 71$ gibi yüksek oranlarda azaldığı, bu azalmanın K stoklarında \%16 ve \%22, $\mathrm{Mg}$ stoklarında ise $\% 7$ ve $\% 6$ kadar olduğu dikkat çekmektedir. Ca stokları ise ikinci nesil sahil çamı ağaçlandırmalarında birinci nesile göre $\% 52$ kadar artarken genç yapraklılarda yaşlı meşcerelere göre \%39 azalmıştır. Ancak yine azot ve karbon stoklarında olduğu gibi incelenen diğer besin maddesi stoklarında topraklardaki değişkenliğin fazla olması nedeniyle işlem grupları arasında fark 
belirlenememiştir. Piirainen ve ark. (2015) toprakların işlenmesinin başta ölü örtü karbon ve besin stokları olmak üzere mekânsal varyasyonu arttırdığını, ağaçlandırma ve toprak işleme yöntemlerinin karbon ve besin stokları üzerindeki etkisinin anlaşılabilmesi için tüm ekosistemdeki besin maddesi akış ve stoklarının uzun süreli olarak izlenmesi gerektiğini bildirmektedirler. Grand ve ark. (2014) hasat işlemlerinin mikro heterojenliği arttırdığını ifade etmektedir. Bu nedenle benzeri çalışmalarda özellikle aynı örnek alan içinde tek bir toprak çukuru açılmasına ek olarak toprak sondası ya da burgularla daha fazla örnek alınması önerilebilir. Böylece toprak işlemeye bağlı olarak oluşan mekânsal değişkenlikler de stok hesaplamalarına yansıtılabilmiş olacaktır.

Hasat ile ağaçların uzaklaştırılması ve toprak işleme ile ölü örtünün kaldırılmasının topraklardaki besin stoklarının azalmasına neden olduğu birçok araştırmayla ortaya konmuştur. Örneğin Arocena (2000), Kanada'da Duglas göknarı ve ladin kar1şık ormanlarda ölü örtünün kaldırılması ve toprak sıkışmasının sızıntı suyundaki $\mathrm{K}, \mathrm{Ca}$ ve $\mathrm{Mg}$ konsantrasyonları üzerindeki etkilerini incelediği çalışmada, ölü örtünün kaldırılmadığı ve toprakların sıkışmadığı alanlarda sızıntı suyu içindeki konsantrasyonların daha fazla olduğunu belirlemiştir. Zhou ve ark. (2015) tarafından da Çin'de Cunninghamia lanceolata, Pinus massoniana ve yapraklı karışık ormanlarda tıraşlama kesimlerden sonraki 10 ve 15 yilda topraklardaki P ve K konsantrasyonlarının azaldığını ifade edilmektedir. Palviainen ve ark. (2014), Finlandiya'da ladin, sarıçam ve yaprak11 karışık ormanlarda yaptıkları çalışmada tıraşlama kesimleri ile toprak işlemenin yüzeysel akışı ve yüzeysel akışla birlikte azot ve fosforun taşınmasını arttırdığını ortaya koymuşlardır. Genel olarak tıraşlama şeklindeki hasat işlemleri ve hasat işlemi sonrasındaki kök sökme ile tekrar ağaçlandırma işlemleri topraklardaki besin maddesi stoklar1n1 azaltmaktadır (Thiffault ve ark., 2011). Ancak zamanla ağaçların gelişerek kapalılığın oluşması ve ölü örtü birikimi ile birlikte topraktaki besin maddesi konsantrasyonları artabilmektedir. Nitekim Peihua ve ark. (2000), Çin'de 25 yaşlarındaki birinci ve ikinci nesil Larix ağaçlandırmalarında toplam N, P, K ve Ca konsantrasyonları arasında fark bulamamışlardır.

\section{4. Öneriler}

Endüstriyel ağaçlandırmalar odun hammaddesi ihtiyacının karşılanması açısından gittikçe önem kazanmaktadır. Türkiye'de 2. rotasyon endüstriyel ağaçlandırmalara yeni başlanmıştır. Uluslararası literatürde özellikle kısa idare süreli rotasyonların dal, yaprak ve köklerin tamamının hasat edilmesi durumunda ölü örtü ile topraklardaki organik karbon ve besin maddesi stoklarını azalttığ1 yönünde araştırmalar mevcuttur. Hatta 2. ve 3. rotasyonlarda ağaçlarda artım kayıpları olabileceği de belirtilmektedir (Walmsley ve ark., 2009; Thiffault ve ark., 2011). Toprakların organik karbon ve besin maddesi açısından fakirleşmemesi için kesim artıklarının tamamının olmasa bile en azından en fazla besin maddesi içeren yaprak ve dalların ormanda birakılmasının (Proe ve Dutch, 1994) etkileri ile homojen yetişme ortamlarında değişik idare süreleri ile gerçekleştirilen endüstriyel ağaçlandırmaların sadece ölü örtü ve toprakta değil, ağaçlar ve diri örtülerdeki karbon ve besin maddesi stoklarını nasıl etkilediği konusunda araştırmalara ihtiyaç bulunmaktadır.

\section{Teşekkür}

$\mathrm{Bu}$ çalışma İZT-392 (6702)/2015-2018 numaralı proje kapsamında Orman Genel Müdürlüğü, Kavak ve Hızlı Gelişen Orman Ağaçları Araştırma Enstitüsü tarafından desteklenmiştir. İstanbul Üniversitesi-Cerrahpaşa Lisansüstü Eğitim Enstitüsü Orman Mühendisliği Anabilim Dalı Toprak İlmi ve Ekoloji Programında Hazırlanmış "İzmitKerpe yöresindeki sahil çamı ağaçlandırmalarının topraktaki ve ölü örtüdeki organik karbon ve besin maddesi stoklarına etkisi” başlıklı Yüksek Lisans Tezinin özetidir.

\section{Kaynaklar}

Arocena, J.M., 2000. Cations in solution from forest soils subjected to forest floor removal and compaction treatments. Forest Ecology and Management 133: 71-80.

Chen, G.S., Yang, Y.S., Xie, J.S., Guo J.F., Gao, R., Qian, W., 2005. Conversion of a natural broad-leafed evergreen forest into pure plantation forests in a subtropical area: Effects on carbon storage. Annals of Forest Science 62 (7): 659-668.

Clarke, N., Gundersen, P., Jönsson-Belyazid, U., Kjønaas, O.J., Persson, T., Sigurdsson, B.D., Stupak, I., Vesterdal, L., 2015. Influence of different tree-harvesting intensities on forest soil carbon stocks in boreal and northern temperate forest ecosystems. Forest Ecology and Management 351: 9-19.

Cooling, E.N.G., 1977. Industrial forestry plantations, Turkey, final report: Plantation silviculture. Working doc no: 28. UNDP/FAO, Rome.

Çömez, A., 2010. Sündiken Dağlar'ında sarıçam (Pinus sylvestris L.) meşcerelerinde karbon birikiminin belirlenmesi. Doktora Tezi, İstanbul Üniversitesi, Fen Bilimleri Enstitüsü. XV+233 sayfa.

Egnell, G., Jurevics, A., Peichl, M., 2015. Negative effe- 
cts of stem and stump harvest and deep soil cultivation on the soil carbon and nitrogen pools are mitigated by enhanced tree growth. Forest Ecology and Management 338: 57-67.

Ercan, M., 2002, Kerpe Araştırma Ormanı (Derleme), Kavak ve Hızlı Gelişen Orman Ağaçları Araştırma Enstitüsü çeşitli yayınlar no: 15, Kocaeli.

Ferré, C., Comolli, R., Leip, A., Seufert, G., 2014. Forest conversion to poplar plantation in a Lombardy floodplain (Italy): Effects on soil organic carbon stock. Biogeosciences 11: 6483-6493.

Gaddas, R.R., 1976. Industrial forestry plantations, Turkey, survey report. Kefken pilot plantation working doc. no:20. UNDP/FAO, Rome.

Gaddas, R.R., Öz, C., 1975. Kefken Pilot Ağaçlandırma Sahas1 Vejetasyon Haritas1, Kocaeli.

Grand, S., Hudson, R., Lavkulich, L.M., 2014. Effects of forest harvest on soil nutrients and labile ions in podzols of southwestern Canada: Mean and dispersion effects. Catena 122: 18-26.

Gülçur, F., 1974. Toprağın Fiziksel ve Kimyasal Analiz Metodları. İstanbul Üniversitesi yayın no: 1970, Orman Fakültesi yayın no: 201, İstanbul.

Hızal, A., Şengönül, K., Zoralioğlu, T., 1991. Çeşitli toprak işleme yöntemleri ile işlenmiş ince tekstürlü toprakların bazı fiziksel özelliklerinde zamanla meydana gelen değișmeler ve bunların Pinus pinaster Aiton plantasyonlarının büyümesi üzerine etkileri. Doğa Türk Tarim ve Ormancllık Dergisi 15 (1): 89-94.

Hızal, A., Zoralioğlu, T., Zengin, M., 2010. Çeşitli toprak işleme yöntemleriyle işlenmiş toprakların bazı fiziksel özelliklerinde zamanla meydana gelen değişimler ile bunların Pinus pinaster Aiton ağaçlandırmalarının büyümesine etkileri. Kavak ve Hızlı Gelișen Orman Ağaçları Araştırma Enstitüsü çeşitli yayınlar no: 21.

Hızal, A., Zengin, M., Karakaş, A., Gökbulak, F., Ercan, M., Tuğrul, D., 2015. Hızlı gelişen orman ağacı türleri ile kurulan endüstriyel ağaçlandırmaların uzun süreçte toprakların kimyasal özelliklerine etkileri. Kavak ve Hızlı Gelişen Orman Ağaçları Araştırma Enstitüsü Müdürlüğü yayın no: 273, çeşitli yayınlar serisi no: 28 .

Jandl, R., Lindner, M., Vesterdal, L., Bauwens, B., Baritz, R., Hagedorn, F., Johnson, D.W., Minkkinen, K., Byrne, K.A., 2007. How strongly can forest management influence soil carbon sequestration? Geoderma 137: 253-268.

Kacar, B., 1972. Bitki ve Toprağın Kimyasal Analizleri: II. Ankara Üniversitesi Ziraat Fakültesi yayın no: 453, Ankara.

Kacar, B., 2009. Toprak Analizleri (Genişletilmiş 2. Basım). Nobel Yayın Dağıtım yayın no: 1387, Ankara.

Kantarcı, M.D., 1981. Ağaçlandırmalarda toprak ișleme usullerinin yetişme ortamındaki besin maddeleri ve bitkisel kütle üretimi üzerine etkileri (Bildiri 14 sayfa). Türkiye'de hızlı gelişen türlerle endüstriyel ağaçlandırmalar simpozyumu, İzmit (Kefken) - Koru Dağ - Çanakkale (Dardanos), 21-26 Eylül 1981.

Kantarcı, M.D., 1982. Ağaçlandırma alanlarında arazi hazırlığı ve toprak işlemesinin orman yetişme orta$\mathrm{m} 1$ üzerindeki etkileri. İstanbul Üniversitesi Orman Fakültesi Dergisi Seri: B 32(2): 52-93.

Kantarc1, M.D., 1983. Kerpe TUR-71/571 ağaçlandırma alanında uygulanan toprak işlemesi yöntemlerinin toprak özellikleri ve sahil çamı fidanlarının gelișimi üzerindeki etkileri. İstanbul Üniversitesi Orman Fakültesi Dergisi Seri: A 33(2): 104-140.

Kantarc1, M.D., 2000. Toprak İlmi. İ.Ü. Orman Fakültesi yayın no: 462, İstanbul.

Li, X., Ye, D., Liang, H., Zhu, H., Qin, L., Zhu, Y., Wen, Y., 2015. Effects of successive rotation regimes on carbon stocks in eucalyptus plantations in subtropical china measured over a full rotation. Plos-One 10(7).

Makineci, E., 1999. İstanbul Üniversitesi Orman Fakültesi Araştırma Ormanındaki Baltalıkların Koruya Dönüştürülmesi İşlemlerinin Ölü Örtü ve Topraktaki Azot Değişimine Etkileri. Doktora Tezi. İstanbul Üniversitesi Fen Bilimleri Enstitüsü, İstanbul.

Makineci, E., Yılmaz, E., Kumbaş11, M., Sevgi, O., Yı1maz, H., Çalışkan, S., Özdemir, E., Beşkardeş, V., Keten, A., Zengin, H., 2011. Kuzey Trakya koruya tahvil meşe ekosistemlerinde sağlık durumu, biyokütle, karbon depolama ve faunistik özelliklerin belirlenmesi. TÜBİTAK-TOVAG tarafından desteklenmiş 1070750 no.lu proje.

MGM, 2015. Meteoroloji Genel Müdürlüğü, İzmit Meteoroloji İstasyonu meteorolojik verileri (1993-2014).

Nave, L.E., Vance, E.D., Swanston, C.W., Curtis, P.S., 2010. Harvest impacts on soil carbon storage in temperate forests. Forest Ecology and Management 259: 857-866.

Nieminen, M., 2004. Export of dissolved organic carbon, nitrogen and phosphorus following clear-cutting of three Norway spruce forests growing on drained peatlands in southern Finland. Silva Fennica 38 (2): 123-132.

OGM, 2013. Orman Genel Müdürlüğü Endüstriyel Ağaçlandırma Çalışmaları Eylem Planı (2013-2023), Ankara.

OGM, 2016. Türkiye Orman Envanteri (2015 Sonu İtibarıyla), ENVANIS, Orman Genel Müdürlüğü.

Özel, C., Güner, Ş.T., Türkkan, M., Akgül, S., Şentürk, Ö., 2020. Modelling the site index of Pinus pinaster plantations in Turkey using ecological variables. Journal of Forestry Research. https://doi.org/10.1007/s11676020-01113-x

Özyuvac1, N., 1978. Kocaeli Yarımadası Topraklarında Erozyon Eğiliminin Toprak Özelliklerine Bağlı Olarak Değişimi. İstanbul Üniversitesi yayın no: 2328, Orman Fakültesi yayın no: 233, İstanbul. 
Palviainen, M., Fine'r, L., Kurka, A.-M., Mannerkoski, H., Piirainen, S., Starr, M., 2004. Decomposition and nutrient release from logging residues after clear-cutting of mixed boreal forest. Plant and Soil 263: 53-67.

Palviainen, M., Fine'r, L., Laure'n, L., Launiainen, S., Piirainen, S., Mattsson, T., Starr, M., 2014. Nitrogen, phosphorus, carbon, and suspended solids loads from forest clear-cutting and site preparation: Long-term paired catchment studies from Eastern Finland. AMBIO 43: 218-233.

Peihua, W., Suhua, X., Wenjuan, J., Yabin, L., Yuying, S., 2000. Effects of the second-generation larch plantations on soil fertility and tree growth. Journal of Forestry Research 11(1): 41-43.

Piirainen, S., Finér, L., Starr, M., 2015. Changes in forest floor and mineral soil carbon and nitrogen stocks in a boreal forest after clear-cutting and mechanical site preparation. European Journal of Soil Science 66(4): 735-743.

Proe, M.F., Dutch, J., 1994. Impact of whole-tree harvesting on second-rotation growth of sitka spruce: the first 10 years. Forest Ecology and Management 66: 39-54.

Prescott, C.E., Maynard, D.G., Laiho, R., 2000. Humus in northern forests: friend or foe?. Forest Ecology and Management 133: 23-36.

Ruiz-Peinado, R., Bravo-Oviedo, A., Lo'pez-Senespleda, E., Montero G., Río, M., 2013. Do thinnings influence biomass and soil carbon stocks in Mediterranean maritime pinewoods?, European Journal of Forest Research 132: $253-262$

Saatçioğlu, F., 1969. Silvikültür I- Silvikültürün Biyolojik Esaslar1 ve Prensipleri. İstanbul Üniversitesi Orman Fakültesi yayın no: 1429/138, İstanbul.

Scott, D.A., Messina, M.G., 2010. Soil properties in 35 y old pine and hardwood plantations after conversion from mixed pine-hardwood forest. American Midland Naturalis 163: 197-211.

Tecimen, H.B., 2005. Dikimle Yetiştirilmiş Sahilçamı (Pinus pinaster Aiton) Ormanında Ayıklama İşlemlerinin Meşceredeki Azot Dolaşımına ve Ağaçların Gelişimine Etkileri. Doktora Tezi. İstanbul Üniversitesi Fen Bilimleri Enstitüsü, İstanbul. XIII+271 sayfa.

Thiffault, E., Hannam, K.D., Paré, D., Titus, B.D., Hazlett, P.W., Maynard, D.G., Brais, S., 2011. Effects of forest biomass harvesting on soil productivity in boreal and temperate forests- A review. Environmental Reviews 19 (NA): 278-309.

Thornthwaite, C.W., 1948. An Approach toward a Rational Classification of Climate. Geographical Review, vol. 38 , pp. 55-94.

TS 8338, 1990. Topraklar-Fosfor Tayini (Modifiye Bray ve Kurtz No:1 Metodu) Türk Standardları Enstitüsü, Ankara.

TS ISO 11265, 1996. Toprak Kalitesi-Elektriksel Öziletkenlik Tayini, Türk Standardları Enstitüsü, Ankara.

TS ISO 10390, 2013. Toprak Kalitesi-pH Tayini, Türk Standardları Enstitüsü, Ankara.

Tolay, U., Hızal, A., Dönmez, E., 1983. Çeşitli toprak işleme yöntemlerinin Kerpe yöresindeki bozuk baltalıklarda ince tekstürlü toprakların fiziksel özellikleri ve ağaçlandırma başarısı üzerine etkileri. Doğa Bilim Dergisi, Tarım ve Ormancılık 7: 171-175.

Tolunay, D., Çömez, A., 2008. Türkiye Ormanlarında toprak ve ölü örtüde depolanmış organik karbon miktarları, Hava Kirliliği ve Kontrolü Ulusal Sempozyumu, Hatay, 22-25 Ekim 2008.

Tolunay, D., Makineci, E., Şahin, A., Özturna, A.G., Pehlivan, S., Abdalmoula, M.M., 2017. İstanbul-Durusu Kumul Alanlarındaki sahil çamı (Pinus pinaster Ait.) ve fıstık çamı (Pinus pinea L.) ağaçlandırmalarında karbon birikimi. TÜBİTAK TOVAG tarafindan desteklenen 1140797 no.lu proje.

Tunçtaner, K., Tulukçu, M., Toplu, F., 1985. Türkiye'de endüstriyel ağaçlandırmalarda kullanılabilecek sahil çamı (Pinus pinaster Ait.) orijinlerinin seçimi üzerine araştırmalar. Kavak ve Hızlı Gelişen Yabancı Tür Orman Ağaçları Araştırma Enstitüsü yıllık bülten no: 21.

Wall, A., 2008. Effect of removal of logging residue on nutrient leaching and nutrient pools in the soil after clearcutting in a Norway spruce stand. Forest Ecology and Management 265: 1372-1383.

Wall, A., Hytönen, J., 2011. The long-term effects of logging residue removal on forest floor nutrient capital, foliar chemistry and growth of a Norway spruce stand. Biomass and Bioenergy 35: 3328-3334.

Walmsley, J.D., Jones, D.L., Reynolds, B., Price, M.H., Healey, J.R., 2009. Whole tree harvesting can reduce second rotation forest productivity. Forest Ecology and Management 257: 1104-1111.

Zengin, M., 1998. Farklı meşçereler altındaki ölü örtü ve toprakların bazı hidro-fiziksel özellikleri. Kavak ve Hızlı gelişen Orman Ağaçları Araştırma Enstitüsü çeşitli yayınlar serisi no: 12 .

Zhang, X.Q., Kirschbaum, M.U., Hou Z., Guo, Z., 2004. Carbon stock changes in successive rotations of Chinese fir (Cunninghamia lanceolata (Lamb) Hook) plantations. Forest Ecology and Management 202: 131-147.

Zhou, X., Zhou, Y., Zhou, C., Wu, Z., Zheng, L., Hu, X., Chen, H., Gan, J., 2015. Effects of cutting intensity on soil physical and chemical properties in a mixed natural forest in southeastern China. Forests 6: 4495-4509. 